Article

\title{
Vertical Ozone Gradients above Forests. Comparison of Different Calculation Options with Direct Ozone Measurements above a Mature Forest and Consequences for Ozone Risk Assessment
}

\author{
Giacomo Gerosa * (D), Riccardo Marzuoli (D), Beatrice Monteleone, Maria Chiesa and Angelo Finco \\ Department of Mathematics and Physics, Catholic University of Brescia, via Musei 41, I-25121 Brescia, Italy; \\ riccardo.marzuoli@unicatt.it (R.M.); beatrice.monteleone@unicatt.it (B.M.); maria.chiesa@unicatt.it (M.C.); \\ angelo.finco@unicatt.it (A.F.) \\ * Correspondence: giacomo.gerosa@unicatt.it; Tel.: +39-030-240-6719
}

Received: 13 July 2017; Accepted: 6 September 2017; Published: 9 September 2017

\begin{abstract}
The estimation of the ozone $\left(\mathrm{O}_{3}\right)$ stomatal dose absorbed by a forest is a crucial step for $\mathrm{O}_{3}$ risk assessment. For this purpose, data on $\mathrm{O}_{3}$ concentrations at the forest top-canopy are needed. However, $\mathrm{O}_{3}$ is barely measured at that height, while more often it is measured at a lower height above a different surface, typically a grassland near to the forest edge. The DO3SE model for $\mathrm{O}_{3}$ stomatal flux calculation estimates the top-canopy $\mathrm{O}_{3}$ concentration in near neutral stability conditions. However, near-neutrality is quite rare in the field, particularly in southern Europe. In this work, we present a modification of the DO3SE gradient calculation scheme to include the atmospheric stability. The performance of the new calculation scheme was tested against the direct measurements above a mature forest. Different gradient estimation options were also tested and evaluated. These options include simplified gradient calculation schemes and the techniques of the tabulated gradients described in the UN/ECE Mapping Manual for $\mathrm{O}_{3}$ risk assessment. The results highlight that the inclusion of the atmospheric stability in the DO3SE model greatly improves the accuracy of the stomatal dose estimation. However, the simpler technique of the tabulated gradients had the best performance on a whole-season time frame.
\end{abstract}

Keywords: ozone stomatal dose; mature mixed oak-hornbeam forest; ozone vertical gradient; atmospheric stability; MOST; Mapping Manual UN/ECE; Bosco Fontana

\section{Introduction}

It has been reported that ozone levels have increased in the last decades both in rural and urban areas [1] while ozone peak values have decreased. Ozone negative effects on forest trees have been reported in a number of experimental trials (e.g., [2,3]) as well as in field observations (e.g., [4,5]).

The estimation of the accumulated ozone dose absorbed by a forest is a crucial step in every ozone risk assessment procedure. For this reason, ozone concentration just at the top of the forest canopy is needed. However, very few $\mathrm{O}_{3}$ concentrations are measured at that height and more often they are measured at a lower height above a different surface, typically a grassland outside the forest edge where the meteorological station is located.

Above and below any measuring point over a vegetated surface, ozone shows a vertical gradient. This gradient, common to every scalar, assumes a typical logarithmic shape described by the Monin-Obukhov similarity theory (MOST), with a minimum ozone concentration near the vegetated surface and an increasing ozone concentration departing vertically from it.

The magnitude of this increase depends on several factors related to the characteristics of the surface (e.g., the geometry of the canopies and canopy shading [6]), to the rate of $\mathrm{O}_{3}$ consumption 
by vegetation (through stomatal uptake and non-stomatal deposition) and soil [7], to the in-canopy chemical reactions $[8,9]$ and to the stability conditions of the atmosphere as discussed, e.g., in Tuovinen and Simpson (2008) [10].

However, it is worth reiterating that the logarithmic shape of the gradient profiles predicted by the MOST should be regarded as a theoretical idealization. In the real world, many scalars measured in forest canopies may not exhibit MOST style decay, for example, when chemical reactions take place [9].

Moreover, the requirements of MOST are not always met in plant canopies, despite the ubiquitous application of this theory. These requirements include, e.g., the stationarity of scalars, the absence of sources and sinks between the measuring height and the exchanging surface, and the horizontal homogeneity of the underlying surface which fails when forest edges are present [11]. The reader can refer to Finnigan [12] and Katul et al. [13] for a complete critical review.

The direct consequence of the existence of an ozone gradient above the vegetation is that the direct use of the concentrations measured above the vegetation (Figure 1A) without any gradient correction will lead to an overestimation of the exposure and phytotoxic dose.

The situation is even more complicated when no measurements at all are available from above the forest top-canopy, and only measurements taken at the standard height ( $2 \mathrm{~m}$ ) of a nearby automatic air quality monitoring station can be accessible. This latter is by far the most common situation, and is well represented in Figure 1B [14].

In this case, measurements at 2-5 $\mathrm{m}$ above the ground may underestimate ozone concentration at the top of the forest canopy (Figure 1B).

To cope with this problem, the DO3SE (Deposition of Ozone for Stomatal Exchange) model [15], which is widely used to estimate the stomatal ozone fluxes to vegetation across Europe, implemented a methodology to estimate the top-forest $\mathrm{O}_{3}$ concentration based on the MOST. This methodology, firstly outlined by Tuovinen et al. [14], is partially described in the Mapping Manual of the CLRTAP (Convention on Long-Range Transboundary Air Pollution) of the UN/ECE (The United Nations Economic Commission for Europe) [16] and assumes the near neutrality atmospheric stability condition, which is very rare in field conditions, particularly in southern Europe.

In this work, we present a modification of the DO3SE gradient calculation scheme to explicitly account for the different atmospheric stability conditions, as introduced by Tuovinen and Simpson [10]. For this purpose, the similarity functions $\Psi_{\mathrm{M}}$ and $\Psi_{\mathrm{H}}$ [17] and the stability parameter $L$ (Monin-Obukhov length) have been introduced in the equations to calculate the atmospheric resistance to ozone $R_{a}$ and the friction velocity $u^{*}$. Then, we extended the calculation scheme for the estimation of the top-canopy ozone concentration over a forest to the case in which the ozone concentrations are measured on a grassy area apart from the target forest. Furthermore, we tested the performance of the new calculation scheme by comparing the calculated top-canopy $\mathrm{O}_{3}$ concentrations with real data, i.e., with the ozone concentrations directly measured above a mature forest during the whole year 2013.

The calculations were made on the ozone concentrations and meteorological measurements at $2 \mathrm{~m}$ a.g.l. (above ground level), available from an air quality monitoring station. This monitoring station was located above a short grass field, a few kilometers upwind of the forest edge, in an area where the ozone concentration field is homogeneous [18].

Different gradient estimation options with increasing levels of data input requirements were tested and evaluated. These options included simplified gradient calculation schemes and the techniques of the tabulated gradients described in the UN/ECE Mapping Manual for ozone risk assessment [16].

The consequences of these gradient calculation methods on the estimation of the ozone stomatal dose taken up by the forest were assessed by comparing the calculated Phytotoxic Ozone Dose (POD) with the $\mathrm{O}_{3}$ stomatal flux derived from direct eddy covariance measurements performed above the forest top-canopy. 


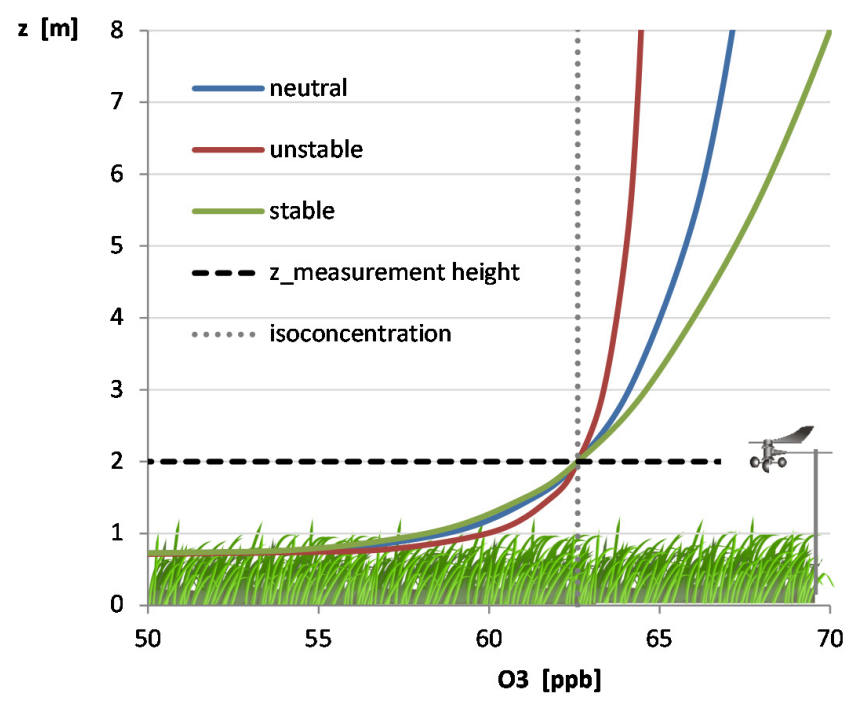

A

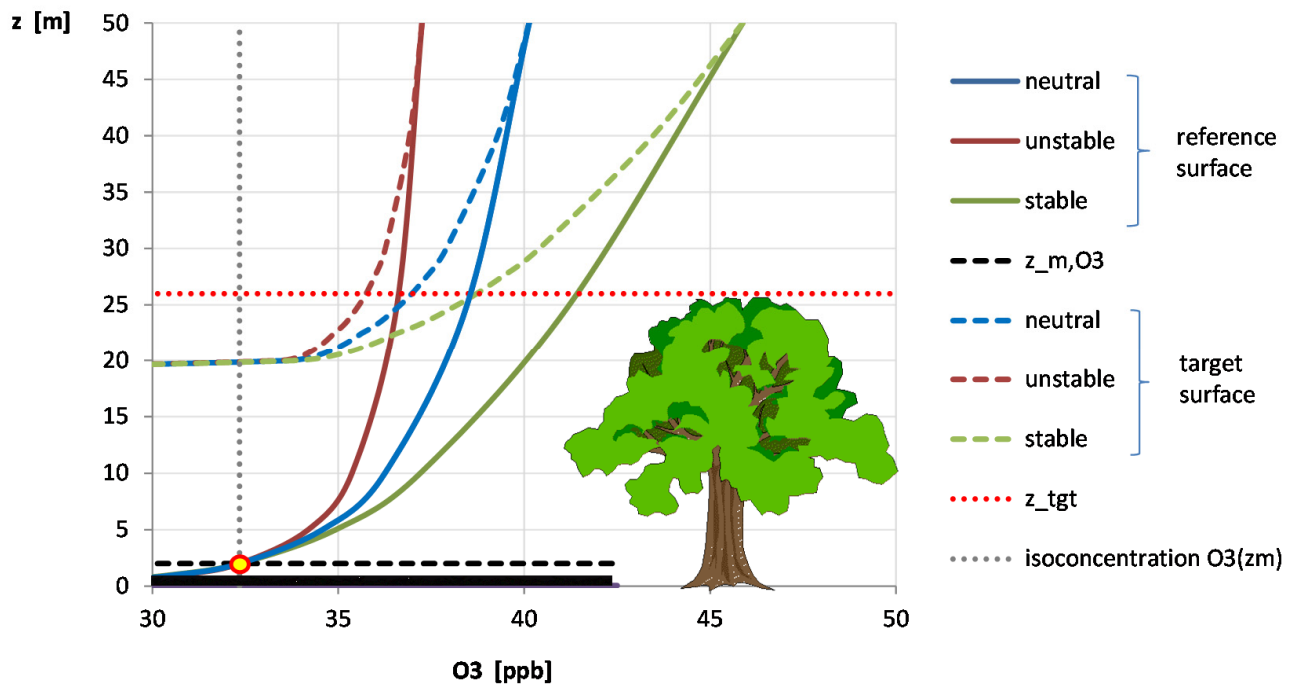

B

Figure 1. Ozone gradients with different atmospheric stability conditions (neutral, stable, unstable). A Gradients above crops when $\mathrm{O}_{3}$ is measured above the canopy top. B gradients above a forest (target surface) when $\mathrm{O}_{3}$ concentration is measured above a reference surface with lower vegetation near to the forest edge at a height which is lower than the forest top-canopy height. Thick curves are the $\mathrm{O}_{3}$ gradients above the reference surface generated from the measuring point (yellow/red dot); dashed curves are the $\mathrm{O}_{3}$ gradients above the forest canopy. 


\section{Materials and Methods}

2.1. Estimation of Ozone Concentrations at the Top of the Forest Canopy from Measurements Taken above a Nearby Short Grassland

Ozone concentrations measured over a short grassland were used to estimate the $\mathrm{O}_{3}$ concentrations at a reference height greater than the forest height, and then the appropriate gradient profile for the forest surface was applied to derive the concentrations at the top of the forest canopy.

The situation is described in Figure 2, where $\mathrm{O}_{3}\left(z_{m, \mathrm{O} 3}\right)$ and $u\left(z_{m, \mathrm{O} 3}\right)$ are the ozone concentration and the wind speed measured over the grassland (hereafter called reference surface) at the measuring heights $z_{m, \mathrm{O} 3}$ and $z_{m, w}$ respectively. The aerodynamic features of the reference surface have been reported in Table 1 while the calculation of all the resistances to ozone deposition over the reference surface $\left(r_{a}, r_{b}\right.$, $\left.r_{\text {stom }}, r_{\text {ext }}, r_{\text {inc }}, r_{\text {soil }}\right)$ will be described below. Table 1 reports also the aerodynamic features of the target surface (e.g., forest). The resistances to ozone deposition over the forest $\left(R_{a}, R_{b}, R_{\text {stom }}, R_{\text {ext }}, R_{\text {inc }}, R_{\text {soil }}\right)$ will be also described below.

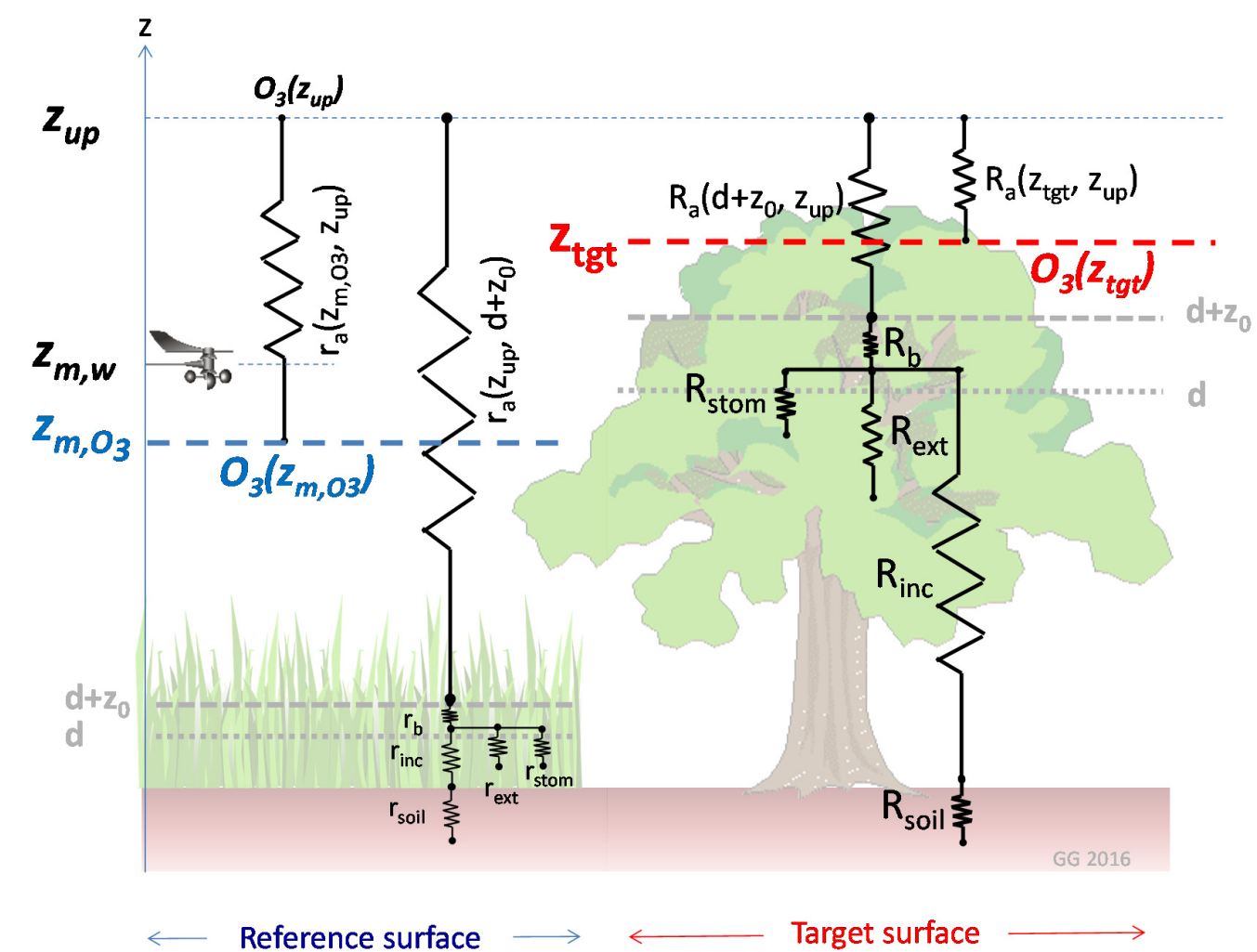

Figure 2. Resistive network for the calculation of the $\mathrm{O}_{3}$ concentration at the top a target canopy (e.g., forest) when ozone and meteorological measurements are available above a different vegetated surface (e.g., grassland). Uppercase resistances refer to the forest while lowercase resistances refer to the grassland. See the text for the meaning of the symbols.

The ozone concentration at the top of the forest canopy (the target height $z_{\text {tgt }}$ ) was obtained with the big-leaf model approximation [6] and the constant-flux assumption [5] for the definition of the aerodynamic resistances. In the following, the roughness sub-layer affecting the concentration profiles near the canopy top was neglected, but a method for correcting the roughness sub-layer can be found in [10]. Moreover, extensive homogeneous surfaces (i.e., an adequate fetch) were assumed and the measurements used were not taken too close to the forest edge [14]. 
Table 1. Parameters used for the gradient calculation exercise. For the meaning of the parameters listed in the section 'Stomatal conductance' of the Table, please refer to the Mapping Manual UN/ECE [16].

\begin{tabular}{|c|c|c|c|c|}
\hline \multirow{2}{*}{$\begin{array}{c}\text { Geometry } \\
\text { Canopy height }\end{array}$} & \multicolumn{2}{|c|}{ Grassland (Reference surface) } & \multicolumn{2}{|c|}{ Forest (Target surface) } \\
\hline & $\mathrm{h}_{\mathrm{ref}}$ & $0.05 \mathrm{~m}$ & $h_{\text {tgt }}$ & $26 \mathrm{~m}$ \\
\hline Displacement height & $d_{\text {ref }}$ & $0.035 \mathrm{~m}$ & $d_{\text {tgt }}$ & $18.2 \mathrm{~m}$ \\
\hline Roughness length & $z_{0, \text { ref }}$ & $0.005 \mathrm{~m}$ & $z_{0, \operatorname{tgt}}$ & $2.6 \mathrm{~m}$ \\
\hline Leaf Area Index & LAI & 3.5 & LAI & 3.5 \\
\hline Surface Area Index & SAI & 3.5 & SAI & 4.5 \\
\hline$\left[\mathrm{O}_{3}\right]$ measuring height & $\mathrm{Z}_{\mathrm{m}, \mathrm{O} 3}$ & $2 \mathrm{~m}$ & & \\
\hline Wind speed measuring height & $\mathrm{Z}_{\mathrm{m}, \mathrm{w}}$ & $2 \mathrm{~m}$ & & \\
\hline Target height for $\left[\mathrm{O}_{3}\right]$ calc. & & & $z_{\text {tgt }}$ & $24 \mathrm{~m}$ \\
\hline Decoupling height & $\mathrm{z}_{\text {up }}$ & $50 \mathrm{~m}$ & & \\
\hline \multicolumn{5}{|l|}{ Constant Resistances } \\
\hline Cuticular resistance to $\mathrm{O}_{3}$ dep. & $\mathrm{r}_{\mathrm{ext}}$ & $2500 \mathrm{~s} / \mathrm{m}$ & $R_{\text {ext }}$ & $2500 \mathrm{~s} / \mathrm{m}$ \\
\hline Soil resistance to $\mathrm{O}_{3}$ dep. & $\mathrm{r}_{\text {soil }}$ & $200 \mathrm{~s} / \mathrm{m}$ & $\mathrm{R}_{\text {soil }}$ & $200 \mathrm{~s} / \mathrm{m}$ \\
\hline \multicolumn{5}{|l|}{ Stomatal Conductance (gs) } \\
\hline Maximum $g_{s}$ to $\mathrm{H}_{2} \mathrm{O}$ & $\mathrm{g}_{\max , \mathrm{H} 20}$ & $270 \mathrm{mmol} \mathrm{m}^{-2} \mathrm{~s}^{-1}$ & $\mathrm{~g}_{\max , \mathrm{H} 20}$ & $230 \mathrm{mmol} \mathrm{m}^{-2} \mathrm{~s}^{-1}$ \\
\hline Fmin & $\mathrm{f}_{\min }$ & 0.01 & $\mathrm{f}_{\min }$ & 0.06 \\
\hline fPAR & $\mathrm{a}_{\text {light }}$ & 0.009 & $\mathrm{a}_{\text {light }}$ & 0.003 \\
\hline \multirow[t]{4}{*}{ fT } & $\mathrm{T}_{\min }$ & $12{ }^{\circ} \mathrm{C}$ & $\mathrm{T}_{\min }$ & $0^{\circ} \mathrm{C}$ \\
\hline & $\mathrm{T}_{\mathrm{opt}}$ & $26^{\circ} \mathrm{C}$ & $\mathrm{T}_{\mathrm{opt}}$ & $20{ }^{\circ} \mathrm{C}$ \\
\hline & $\mathrm{T}_{\max }$ & $40^{\circ} \mathrm{C}$ & $\mathrm{T}_{\max }$ & $35^{\circ} \mathrm{C}$ \\
\hline & $\mathrm{b}$ & 1 & $\mathrm{~b}$ & 0.75 \\
\hline \multirow[t]{2}{*}{ fVPD } & $\mathrm{VPD}_{\max }$ & $1.3 \mathrm{KPa}$ & $\mathrm{VPD}_{\max }$ & $1.0 \mathrm{KPa}$ \\
\hline & $\mathrm{VPD}_{\min }$ & $3.0 \mathrm{KPa}$ & $\mathrm{VPD}_{\min }$ & $3.25 \mathrm{KPa}$ \\
\hline \multirow[t]{2}{*}{ fSWP } & $\mathrm{SWP}_{\min }$ & $-1.5 \mathrm{MPa}$ & $\mathrm{SWP}_{\min }$ & $-1.2 \mathrm{MPa}$ \\
\hline & $\mathrm{SWP}_{\max }$ & $-0.49 \mathrm{MPa}$ & $\mathrm{SWP}_{\max }$ & $-0.5 \mathrm{MPa}$ \\
\hline \multirow[t]{6}{*}{ fPHEN } & SGS & 1 DOY & SGS & 105 DOY \\
\hline & fphen_1 & 0 days & fphen_1 & 20 days \\
\hline & fphen_4 & 0 days & fphen_4 & 30 days \\
\hline & fphen_a & 1 & fphen_a & 0 \\
\hline & fphen_e & 1 & fphen_e & 0 \\
\hline & EGS & 365 DOY & EGS & 297 DOY \\
\hline \multicolumn{5}{|l|}{ Soil Water } \\
\hline Soil type & Clay-loam & & Clay-loam & \\
\hline Water content at field capacity & $\mathrm{SWC}_{\mathrm{fc}}$ & $0.37 \mathrm{~m}^{3} / \mathrm{m}^{3}$ & $\mathrm{SWC}_{\mathrm{fc}}$ & $0.37 \mathrm{~m}^{3} / \mathrm{m}^{3}$ \\
\hline Water content at wilting point & $\mathrm{SWC}_{\mathrm{wp}}$ & $0.1676 \mathrm{~m}^{3} / \mathrm{m}^{3}$ & $\mathrm{SWC}_{\mathrm{wp}}$ & $0.1676 \mathrm{~m}^{3} / \mathrm{m}^{3}$ \\
\hline & $\Psi_{\mathrm{e}}$ & $-0.00588 \mathrm{MPa}$ & $\Psi_{\mathrm{e}}$ & $-0.00588 \mathrm{MPa}$ \\
\hline & $b_{\text {soil }}$ & 7 & $b_{\text {soil }}$ & 7 \\
\hline Root depth & $r_{\text {depth }}$ & $0.80 \mathrm{~m}$ & $r_{\text {depth }}$ & $1.00 \mathrm{~m}$ \\
\hline
\end{tabular}

As a first step, the ozone concentration was calculated at the height $z_{u p}$, which is not influenced by variation in the properties of the underlying surface. This height was assumed to be $50 \mathrm{~m}$ [19] and it is consistent with the outputs of the EMEP (European Monitoring and Evaluation Program) Chemical Transport Model [10] which feeds the DO3SE model.

The $\mathrm{O}_{3}$ concentration at the height $z_{u p}$ is given by:

$$
\mathrm{O}_{3}\left(z_{u p}\right)=\frac{\mathrm{O}_{3}\left(z_{m, \mathrm{O} 3}\right)}{1-\frac{r_{a}\left(z_{m, \mathrm{O} 3}, z_{u p}\right)}{r_{a}\left(d_{r e f}+z_{0}, z_{u p}\right)+r_{b}+r_{\text {surf }}}}
$$

where $\mathrm{O}_{3}\left(z_{m, \mathrm{O} 3}\right)$ is the available ozone measurement above the grassland canopy; $r_{a}\left(z_{m, \mathrm{O}}, z_{u p}\right)$ is the aerodynamic resistance between the height where ozone was measured and the height $z_{\text {up }}$; $r_{a}\left(d_{r e f}+z_{0}, z_{u p}\right)$ is the aerodynamic resistance to ozone deposition, i.e., the atmospheric resistance between the height $z_{\mathrm{up}}$ and the height of the upper boundary of the laminar sub-layer of the theoretical 
big-leaf surface which represents the grassland; $r_{b}$ is the resistance to ozone diffusion in the laminar sub-layer; and $r_{\text {surf }}$ is the overall resistance to ozone deposition, to the grassland leaves and the underlying soil. The latter includes the stomatal resistance to ozone uptake $r_{\text {stom }}$, the resistance of the external cuticles $r_{\text {ext }}$, the soil resistance to ozone deposition $r_{\text {soil }}$ and the air resistance to ozone transfer within the vegetation layer $r_{i n c}$.

The two atmospheric resistances are given by the following expressions:

$$
\begin{gathered}
r_{a}\left(z_{m, \mathrm{O} 3}, z_{u p}\right)=\frac{1}{k \cdot u_{r e f}^{*}}\left[\ln \left(\frac{z_{u p}-d_{r e f}}{z_{m, \mathrm{O}}-d_{r e f}}\right)-\Psi_{H}\left(\frac{z_{u p}-d_{r e f}}{L}\right)+\Psi_{H}\left(\frac{z_{m, \mathrm{O} 3}-d_{r e f}}{L}\right)\right] \\
r_{a}\left(d_{r e f}+z_{0}, z_{u p}\right)=\frac{1}{k \cdot u_{r e f}^{*}}\left[\ln \left(\frac{z_{u p}-d_{r e f}}{z_{0, r e f}}\right)-\Psi_{H}\left(\frac{z_{u p}-d_{r e f}}{L}\right)+\Psi_{H}\left(\frac{z_{0, r e f}}{L}\right)\right]
\end{gathered}
$$

with $u_{r e f}^{*}$ the friction velocity above the reference surface calculated as follows

$$
u_{r e f}^{*}=\frac{k \cdot u\left(z_{m, w}\right)}{\ln \left(\frac{z_{m, w}-d_{r e f}}{z_{0, r e f}}\right)-\Psi_{M}\left(\frac{z_{m, w}-d_{r e f}}{L}\right)+\Psi_{M}\left(\frac{z_{0, r e f}}{L}\right)}
$$

where $k$ is the von Kármán constant $(=0.41[20]) ; u\left(z_{m, w}\right)$ is the wind speed measured at the height $z_{m, w} ; d_{r e f}$ is the displacement height assumed as two-thirds of the canopy height; $z_{0, \text { ref }}$ is the roughness length assumed as 1/10 of the canopy height; and $\Psi_{M}($.$) is the integral form of the similarity function$ for momentum which takes into account the stability of the atmospheric surface layer in terms of the Obukhov length $L(1 / L$ approaches zero if the atmosphere is neutral, $1 / L<0$ if the atmosphere is unstable, $1 / L>0$ if the atmosphere is stable) [17].

Taking the adimensional length $\zeta$ as argument, the function $\Psi_{M}(\zeta)$ is defined by the formulation of Garratt [17]:

$$
\Psi_{M}(\zeta)= \begin{cases}\ln \left[\frac{1+x^{2}}{2} \cdot\left(\frac{1+x}{2}\right)^{2}\right]-2 \arctan (x)+\frac{\pi}{2}, & \text { when } \zeta<0 \\ -5 \zeta & \text { when } \zeta \geq 0\end{cases}
$$

with $x=(1-16 \cdot \zeta)^{1 / 4}$.

Instead, the $\Psi_{H}($.$) function which appears in Equations (2) and (3) is the similarity function for$ heat defined by Garratt [17] as:

$$
\Psi_{M}(\zeta)= \begin{cases}2 \ln \left[\frac{1+x^{2}}{2}\right], & \text { when } \zeta<0 \\ -5, & \text { when } \zeta \geq 0\end{cases}
$$

with $x$ as defined in Equation (5).

The Obukhov length needed to account for the atmospheric stability is defined as in [21]:

$$
L=-\frac{u_{*}^{3}}{k \frac{g}{T} \frac{H}{\rho c_{p}}}
$$

where $u^{*}$ is the friction velocity $(\mathrm{m} / \mathrm{s}), k$ is the Von Kármán constant $(0.41$, adim $), g$ is the gravity acceleration $\left(9.8 \mathrm{~m} \mathrm{~s}^{-2}\right), T$ is the air temperature $(\mathrm{K}), H$ is the sensible heat flux $\left(\mathrm{W} \mathrm{m}^{-2}\right), \rho$ is the air density $\left(\mathrm{kg} \mathrm{m}^{-3}\right), c_{p}$ is the specific heat at constant pressure $\left(1048 \mathrm{~J} \mathrm{~kg}^{-1} \mathrm{~K}^{-1}\right)$.

The values of $u^{*}$ and $H$ for the calculation of $L$ can be obtained from eddy covariance measurements (see the following Section 2.2) or $L$ can be estimated from standard meteorological measurements by following the procedure illustrated in Appendix A. 
The resistance to ozone diffusion in the laminar sub-layer $r_{b}$ has been calculated with the formulation of Wesely and Hicks [7]:

$$
r_{b}=\frac{2}{k \cdot u_{r e f}^{*}}\left(\frac{S c}{P r}\right)^{2 / 3}
$$

where $k$ is the von Kármán constant, $S c=0.93$ is the Schmidt number for ozone [22], and $P r=0.71$ is the Prandtl number for air.

The surface resistance to ozone deposition $r_{\text {surf }}$ was defined as follows:

$$
r_{\text {surf }}=\frac{1}{\frac{L A I}{r_{\text {stom }}}+\frac{S A I}{r_{\text {ext }}}+\frac{1}{r_{\text {inc }}+r_{\text {soil }}}}
$$

where $r_{\text {stom }}$ is the leaf-scale stomatal resistance to ozone of the vegetated surface; $r_{\text {ext }}$ is the leaf-scale resistance of the external vegetation surfaces (e.g., cuticles) to ozone deposition; $r_{\text {soil }}$ is the soil resistance to ozone deposition; $r_{i n c}$ is the in-canopy air resistance to the ozone transfer to the soil; $L A I$ is the projected leaf area index $\left(\mathrm{m}^{2}\right.$ leaves $\mathrm{m}^{-2}$ ground $)$; and $S A I$ is the surface area of the grassland canopy (green $L A I+$ senescent $L A I+$ stem surfaces).

$r_{\text {stom }}$ is a plant species-specific function of air temperature and humidity, solar radiation and soil water content. It was modelled by means of the Jarvis-Stewart algorithm $[15,23]$ as follows:

$$
r_{\text {stom }}=\frac{1}{g_{\text {stom }}}=\frac{1}{g_{\max } \cdot f_{P H E N}(D O Y) \cdot \max \left[f_{\min } ; f_{P A R}(P A R) \cdot f_{T}(T) \cdot f_{V P D}(V P D) \cdot f_{S W P}(S W P)\right]}
$$

where $g_{\max }$ is the stomatal conductance of ozone in non-limiting conditions and the $f$ functions $f_{P H E N}, f_{P A R}, f_{T}, f_{V P D}, f_{S W P}$. are species-specific functions which describe the variation of the stomatal conductance with phenology (i.e., with the DOY = the Julian day of the year), light $(P A R)$, air temperature $(T)$, leaf-to-air vapour pressure deficit $(V P D)$ and soil water potential $(S W P)$, respectively.

For details, please see the section on the modelling of the stomatal conductance in the UN/ECE Mapping Manual [16]. The 'grassland' parameterization was adopted for this comparison (Table 1).

The resistance to the cuticular deposition of $\mathrm{O}_{3}, r_{\text {ext }}$, and the soil resistance to $\mathrm{O}_{3}$ deposition, $r_{\text {soil, }}$ were set respectively to $2500 \mathrm{~s} \mathrm{~m}^{-1}$ and $200 \mathrm{~s} \mathrm{~m}^{-1}$ for consistency with the EMEP model [19].

The in-canopy resistance $r_{i n c}$ was calculated according to van Pul and Jacobs [20]:

$$
R_{\text {inc }}=b \cdot S A I \cdot h / u^{*}
$$

where $b=14 \mathrm{~m}^{-1}$ is an empirical constant, $h$ is the height of the grassland canopy and $S A I$ is the surface area of the canopy.

The conversion of the stomatal conductance values from $m m o l \mathrm{~m}^{-2} \mathrm{~s}^{-1}$ to $\mathrm{m} \mathrm{s}^{-1}$ was done by multiplying them by $R \cdot T / P$ with $R=8.314 \mathrm{~J} \mathrm{~mol}^{-1} \mathrm{~K}^{-1}$ the gas constant, $T$ the air temperature in Kelvin and $P$ the atmospheric pressure in $\mathrm{Pa}$. Stomatal conductances to water vapour were converted to stomatal conductances to ozone by multiplying them by the diffusivity ratio between water and $\mathrm{O}_{3}$, equal to 0.663 .

Once the $\mathrm{O}_{3}$ concentration at the height $z_{u p}$ was known, the $\mathrm{O}_{3}$ concentration at the desired height $z_{\text {tgt }}$ above the forest $\mathrm{O}_{3}\left(z_{t g t}\right)$ could be calculated:

$$
O_{3}\left(z_{\text {tgt }}\right)=O_{3}\left(z_{u p}\right) \cdot\left[1-\frac{R_{a}\left(z_{\text {tgt }}, z_{u p}\right)}{R_{a}\left(d+z_{0}, z_{u p}\right)+R_{b}+R_{\text {surf }}}\right]
$$


where $\mathrm{O}_{3}\left(z_{u p}\right)$ was the $\mathrm{O}_{3}$ concentration calculated with Equation (1), and the two atmospheric resistances-which here refer to the target surface-were given by the following expressions:

$$
\begin{aligned}
& R_{a}\left(z_{\text {tgt }}, z_{u p}\right)=\frac{1}{k \cdot u_{\text {tgt }}^{*}}\left[\ln \left(\frac{z_{u p}-d_{\text {tgt }}}{z_{\text {tgt }}-d_{\text {tgt }}}\right)-\Psi_{H}\left(\frac{z_{u p}-d_{\text {tgt }}}{L}\right)+\Psi_{H}\left(\frac{z_{\text {tgt }}-d_{\text {tgt }}}{L}\right)\right] \\
& R_{a}\left(d+z_{0}, z_{u p}\right)=\frac{1}{k \cdot u_{t g t}^{*}}\left[\ln \left(\frac{z_{u p}-d_{\text {tgt }}}{z_{0, t g t}}\right)-\Psi_{H}\left(\frac{z_{u p}-d_{\text {tgt }}}{L}\right)+\Psi_{H}\left(\frac{z_{0, t g t}}{L}\right)\right]
\end{aligned}
$$

with $\Psi_{H}($.$) the similarity function defined in Equation (6).$

The friction velocity above the forest $u_{t g t}^{*}$ which appears in Equations (13) and (14) was obtained as

$$
u_{t g t}^{*}=\frac{k \cdot u\left(z_{u p}\right)}{\ln \left(\frac{z_{u p}-d_{t g t}}{z_{0, t g t}}\right)-\Psi_{M}\left(\frac{z_{u p}-d_{t g t}}{L}\right)+\Psi_{M}\left(\frac{z_{0, t g t}}{L}\right)}
$$

where $d$ and $z_{0}$ now refer to the forest target surface ('tgt' suffix).

$u\left(z_{u p}\right)$ is the wind speed at the height $\left(z_{u p}\right)$ at which the wind is assumed to be not influenced by variations in the underlying surface, and it was calculated above the grassland surface by the following formula:

$$
u\left(z_{u p}\right)=\frac{u_{r e f}^{*}}{k} \cdot\left[\ln \left(\frac{z_{u p}-d_{r e f}}{z_{0, r e f}}\right)-\Psi_{M}\left(\frac{z_{u p}-d_{r e f}}{L}\right)+\Psi_{M}\left(\frac{z_{0, r e f}}{L}\right)\right]
$$

where $d$ and $\mathrm{z}_{0}$ refer to the reference surface (i.e., the grassland).

The resistance $R_{b}$ which appears in Equation (12) was calculated with Equation (8) by using $u_{t g t}^{*}$ instead of $u_{r e f}^{*}$. The resistance $R_{\text {surf }}$ of Equation (12) was calculated in a way analogous to that explained for the grassland (Equations (9)-(11)) but by taking into account the appropriate geometry, $L A I, S A I$ and the $f$ functions for the forest (target canopy). Here, the parameterization for a 'Temperate oak' forest of the UN/ECE Mapping Manual [16] has been adopted. The soil water parameterisation has been taken from Büker et al. [24].

\subsection{Experimental Data and Site Description}

The experimental data used for this comparison were taken from the measurements made on a 42-m tall tower installed at Bosco Fontana, Italy $\left(45^{\circ} 11^{\prime} 52.2^{\prime \prime} \mathrm{N}, 10^{\circ} 44^{\prime} 31.2^{\prime \prime} \mathrm{E}\right)$ in the summer of 2013 for the ECLAIRE FP7 EU-project.

The measurement site is located inside a 235 hectares nature reserve formed of a mature mixed oak-hornbeam forest on the outskirts of the city of Mantua, in the middle of the Po Valley, Italy.

The tree species of the dominant layer are Carpinus betulus L. and Quercus robur L. (57\%) with a minor presence of Acer campestre L., Prunus avium L., Fraxinus ornus L. and F. oxycarpa Willd., Ulmus minor Mill., and Alnus glutinosa L. along the little rivers.

The dominant tree layer is formed of Corylus avellana, Sambuscus spp, Cornus mas, Crataegus oxyacantha and C. monogyna and Sorbus torminalis, with a dense nemoral layer of Ruscus aculeatus. Alien species are also present: Quercus rubra, Juglans nigra, Platanus orientalis and Robinia pseudoacacia.

The average canopy height at the measuring site was $26 \mathrm{~m}$.

The aspect is flat ( $25 \mathrm{~m}$ a.s.l.) and the site climate is typical of the Po Valley, with cold winters and hot summers [25]. The mean annual temperature in 2013 was $13.97^{\circ} \mathrm{C}$, with an average temperature of $3.34{ }^{\circ} \mathrm{C}$ in the coldest month (February) and $25.94{ }^{\circ} \mathrm{C}$ in the warmest month (July). The annual precipitation was $551 \mathrm{~mm}$ with two maxima in March and October, and a prolonged minimum in May-June. The atmospheric stability during the summer months was unstable or very unstable for more than the $90 \%$ of the hours (Figure 3 ) while the neutral stability conditions were extremely rare 
during the daylight hours $(0.46 \%)$ and rare on a $24 \mathrm{~h}$ basis $(3.8 \%)$. During the same months, the median value of the Monin-Obukhov length $L$ was $-28.3 \mathrm{~m}$.

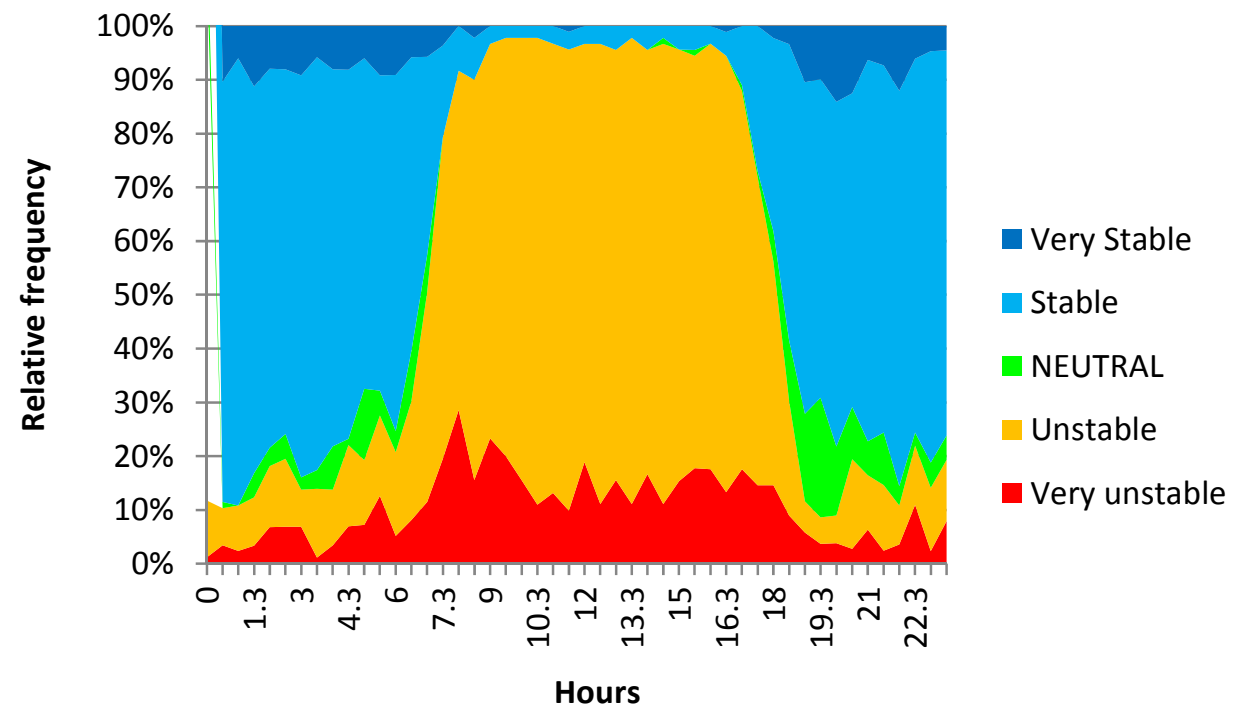

Figure 3. Atmospheric stability conditions between May and July 2013 at the Bosco Fontana forest site.

\subsection{Ozone Concentration Measurements}

Ozone concentrations as well as air temperature and humidity were measured at four heights above ground $(2 \mathrm{~m}, 18 \mathrm{~m}, 30 \mathrm{~m}, 42 \mathrm{~m})$, two of them above and two below the forest canopy. Samples of air from the different levels were directed through four PTFE tubes of the same length $(50 \mathrm{~m})$ to a four-solenoid-valves switching system (TEQCOM, Santa Ana, CA, USA) by a $5 \mathrm{~L} / \mathrm{min}$ pump. A Labview program opened sequentially the four valves conveying the air to an UV-photometer (API 400, Houston, TX, USA) for $\mathrm{O}_{3}$ concentration detection. Each valve remained open for $7 \mathrm{~min}$ and $30 \mathrm{~s}$ : half of the time was used for tubes flushing and analyser stabilization and the remaining time was used for actual $\mathrm{O}_{3}$ concentrations recording.

\subsection{Ozone Flux Measurements and POD Calculation}

Ozone fluxes were measured at the top of the tower with the eddy covariance technique (EC) by means of a chemiluminescent fast ozone analyser (COFA, Ecometrics srl, Brescia, Italy) similar to that described by Güsten et al. [26,27] coupled with a 3-D ultrasonic anemometer (USA-1, Metek, D). The data acquisition frequency was set to $20 \mathrm{~Hz}$.

The raw EC data were despiked [28,29] and a double rotation was applied to the instantaneous wind vectors in order to align the reference $\mathrm{x}$ coordinate to the mean horizontal wind stream direction and to zero the mean vertical wind component [29]. Then, the data were linearly detrended [29,30] and the covariances of the fast vertical wind speed $(w)$ and $\mathrm{O}_{3}$ concentration measurements were calculated, by applying the lag time which maximized the covariances between $w$ and $\mathrm{O}_{3}$.

In order to assess the high frequency flux loss of the sensor, an Ogive-analysis was used, where the cospectra of $\mathrm{w}$ and $\mathrm{O} 3$ were adjusted to match the cospectra of $w$ and the sonic temperature [31]. The correction adopted ranged between 0 and $1.5 \%$ according to the different stability conditions, with a mean value of $1.01 \%$.

The ozone fluxes have been calculated from the covariances of $w$ and $\mathrm{O}_{3}$ by applying the ratiometric method (RM) described by Muller et al. [32].

Finally, a WPL correction $[29,33]$ was applied to account for the density fluctuations due to sensible $(\mathrm{H})$ and latent $(\lambda \mathrm{E})$ heat fluxes. Data quality checks were also applied to ensure the applicability of 
the EC technique. The stationarity condition was checked following Foken and Wichura [34] and non-stationary samples were excluded.

The measured ozone fluxes were then partitioned between a stomatal and a non-stomatal component through the estimation of the bulk stomatal resistance by means of the Penman Monteith equation [35]. For dry and closed canopies, this approach implies an energy balance between the energy received by the canopy with the solar radiation and the energy lost evaporating water from leaves' stomata plus the energy lost as sensible heat toward the atmosphere or inside the ground.

Details on the measuring system and the flux partition procedure can be found in Gerosa et al. [35,36].

Finally, the Phytotoxic Ozone Dose above a threshold of $1 \mathrm{nmol} \mathrm{O}_{3} \mathrm{~m}^{-2} \mathrm{~s}^{-1}\left(\mathrm{POD}_{1}\right)$ was calculated from all the half-hourly stomatal fluxes of the six-month period according to the UN/ECE Mapping Manual and the DO3SE model [16]:

$$
P O D 1=\int(F s t-1) d t
$$

where Fst are the stomatal fluxes of ozone in $\mathrm{nmol} \mathrm{m}^{-2} \mathrm{~s}^{-1}$ and $1\left(\mathrm{nmol} \mathrm{m} \mathrm{m}^{-2} \mathrm{~s}^{-1}\right)$ is the instantaneous flux threshold adopted to account for detoxification in forest trees [16].

\subsection{Simulations and Comparisons (Tested Calculation Options)}

The $\mathrm{O}_{3}$ concentrations measured at $30 \mathrm{~m}$ on the micrometeorological tower of Bosco Fontana from May to October 2013 (during which time plants had leaves) were compared with the $30 \mathrm{~m}$ ozone concentrations estimated above the forest with the procedure illustrated in the previous section starting from the measurements made at $2 \mathrm{~m}$ height on a grassland surface located $4.3 \mathrm{~km}$ away from the tower at Porto Mantovano, in the upwind direction during the daylight hours (E).

The $\mathrm{O}_{3}$ concentrations and the meteorological measurements at $2 \mathrm{~m}$ were taken from the air quality monitoring station of the Regional Agency for Environment Protection (ARPA) of the Lombardy region classified as 'background station'.

The $30 \mathrm{~m} \mathrm{O}_{3}$ concentration above the forest was estimated with the following calculation options:

1. By using a constant $L$ value representing the different theoretical stability classes of the testing area: $1 / L$ approaching 0 for neutral conditions, $1 / L=-0.01$ for unstable conditions, $1 / L=-0.1$ for very unstable conditions, $1 / L=+0.01$ for stable conditions.

2. By using the hourly value of the M-O length $L$ which was obtained:

(a) directly from the eddy covariance measurements;

(b) Bestimation from standard meteorological measurements following the procedure illustrated in Appendix A.

3. By using the seasonal average and the median values of the in situ measured M-O length $L$.

4. By using only Equation (1) to calculate the $\mathrm{O}_{3}$ concentration above the forest top-canopy (by setting $z_{u p}=30 \mathrm{~m}$ ), i.e., by assuming that the $\mathrm{O}_{3}$ gradient above the forest was the same as the one calculated above the grassland, thus neglecting the effect of forest geometry and physiology on the $\mathrm{O}_{3}$ deposition flux.

5. By using the noon concentration gradients tabulated in the UN/ECE Mapping Manual [16] suggested for case studies without available meteorological measurements to estimate the value of the M-O length $L$.

6. By directly using the $\mathrm{O}_{3}$ concentration measured at $2 \mathrm{~m}$ above the grassland as a surrogate of the $\mathrm{O}_{3}$ concentration above the forest top-canopy (no gradients calculation), i.e., by assuming a vertical isoconcentration profile.

Then, the estimated $30 \mathrm{~m} \mathrm{O}_{3}$ concentrations were used to calculate the $\mathrm{POD}_{1}$ of the forest trees by means of this calculation scheme, and the results were compared with the $\mathrm{POD}_{1}$ values obtained 
with the $\mathrm{O}_{3}$ concentrations measured on the micrometeorological tower according to the procedure illustrated in the previous section.

\section{Results}

Figure 4 shows the results of the estimations of the $\mathrm{O}_{3}$ concentration at $30 \mathrm{~m}$ a.g.l. above the forest with the different calculation options. When the theoretical stability classes are used (option 1), the estimate that best matched the measured $\mathrm{O}_{3}$ concentration during the daylight hours was that calculated assuming very unstable conditions (Figure 4A), particularly in the mid-summer months. In the same months, the best match during nighttime was reached when stable conditions were assumed. These results are not surprising observing that the unstable conditions are particularly frequent during daytime while the stable conditions dominate during nighttime (Figure 3). The neutral stability condition, currently assumed in the Mapping Manual [16], implies an overestimation of the ozone concentration by $15 \%$ as a median value on a $24-\mathrm{h}$ basis (Table 2 ).

Table 2. Differences between the calculated and the measured ozone concentrations above the forest using the different calculation options (see text). For comparison purpose: the Neutral case of option 1 is the output of the current version of the DO3SE model.

\begin{tabular}{ccccc}
\hline Calculation options & & & $\begin{array}{c}\text { Max difference with } \\
\text { the } \mathbf{O}_{3} \text { measured }\end{array}$ & $\begin{array}{c}\text { Median difference } \\
\text { with the } \mathbf{O}_{3} \text { measured }\end{array}$ \\
\hline 1-Theoretical stability & Stable & $(L=100 \mathrm{~m})$ & $33 \%$ & $26 \%$ \\
& Neutral & $(L \rightarrow \infty \mathrm{m})$ & $20 \%$ & $15 \%$ \\
& Unstable & $(L=-100 \mathrm{~m})$ & $1 \%$ & $9 \%$ \\
& Very Unstable & $(L=-10 \mathrm{~m})$ & $10 \%$ & $2 \%$ \\
2-Actual stability $\left.{ }^{*}\right)$ & Real stability & $($ measured $L)$ & $12 \%$ & $7 \%$ \\
& Modelled stability & $($ estimated $L)$ & $7 \%$ & $0 \%$ \\
3-Aver. actual stability & Mean stability & $(L=28.2 \mathrm{~m})$ & $12 \%$ & $5 \%$ \\
& Median stability & $(L=32.4 \mathrm{~m})$ & $12 \%$ & $5 \%$ \\
4-Gradients on ref. veg. & Stable & $(L=100 \mathrm{~m})$ & $34 \%$ & $16 \%$ \\
& Neutral & $(L \rightarrow \infty \mathrm{m})$ & $22 \%$ & $10 \%$ \\
& Unstable & $(L=-100 \mathrm{~m})$ & $18 \%$ & $6 \%$ \\
5-Tab. gradients at $26 \mathrm{~m}$ & Stable & $(L=100 \mathrm{~m})$ & $9 \%$ & $2 \%$ \\
6-Isoconcentration & Neutral & $(L \rightarrow \infty \mathrm{m})$ & $-11 \%$ & $-4 \%$ \\
& Unstable & $(L=-100 \mathrm{~m})$ & $-11 \%$ & $-4 \%$ \\
& & & $-4 \%$ \\
\hline
\end{tabular}

* statistic only restricted to daylight hours.

The use of the actual stability (option 2), both derived from the EC measurements or obtained from standard meteorological measurements (modelled L), resulted in better daylight agreement between the estimates and the measurements (Figure 4B). However, during the evening and nighttime, the concentrations estimated with the modelled L are unrealistically high and should be discarded. This happens because the sensible heat flux $\mathrm{H}$ estimated with the methodology reported in Appendix A turns rapidly to negative when the solar radiation fades, and this affects the sign of the stability indicator L (Equation (7)) which turns to stable atmosphere. Moreover, when the sunlight fades, the turbulence fades as well, leading to lower values of the friction velocity. The combined effect leads to low positive values of $L$ which indicates an unrealistically extremely stable and stratified atmosphere, where $\mathrm{O}_{3}$ concentrations increase rapidly with the height.

Nevertheless, since stomata are closed during the night, nighttime $\mathrm{O}_{3}$ concentrations are of little importance (negligible) for the POD1 accumulation. If we restrict the statistics to the daylight hours (as reported in Table 2), $\mathrm{O}_{3}$ concentrations estimated when $\mathrm{L}$ was modelled show a very good agreement with the measured ones $(-0.2 \%$ as median difference), while when $\mathrm{L}$ was taken from the measurements a median overestimation of $7 \%$ was obtained.

The use of the seasonal average of the measured $L$ values (option 3), both as median and mean values, resulted in a better agreement between the estimated and the measured $\mathrm{O}_{3}$ concentrations than using the actual hourly $L$ values from the measurements (option 2): a $5 \%$ overestimation of the median 
$30 \mathrm{~m}$ ozone concentration (Table 2), with a maximum median deviation of $12 \%$ was obtained in June (Figure 4C).

When the $\mathrm{O}_{3}$ gradients were calculated only above the reference surface (option 4), the above canopy $\mathrm{O}_{3}$ concentrations were overestimated by $6 \%$ to $16 \%$ according to the different stability classes (Table 2), with the maximum deviation in the central hours of the day, ranging between $18 \%$ and $34 \%$ (Figure 4D).

The adoption of the noon concentration gradients tabulated in the Mapping Manual (option 5) [16] yielded a good agreement between the estimated and the measured $\mathrm{O}_{3}$ concentrations, with a median deviation of $2 \%$ (Table 2) and a maximum deviation of $9 \%$ in the central hours of the day in June (Figure 4E).

Finally, when no gradient calculations were made at all and a vertical $\mathrm{O}_{3}$ isoconcentration was assumed (option 6), the ground base $\mathrm{O}_{3}$ concentration measured above the grassland underestimated the top forest $\mathrm{O}_{3}$ concentration by a median value of $-4 \%$ (Table 2), and by a maximum deviation of $-11 \%$ in the central hours of the day (Figure $4 \mathrm{~F}$ ).

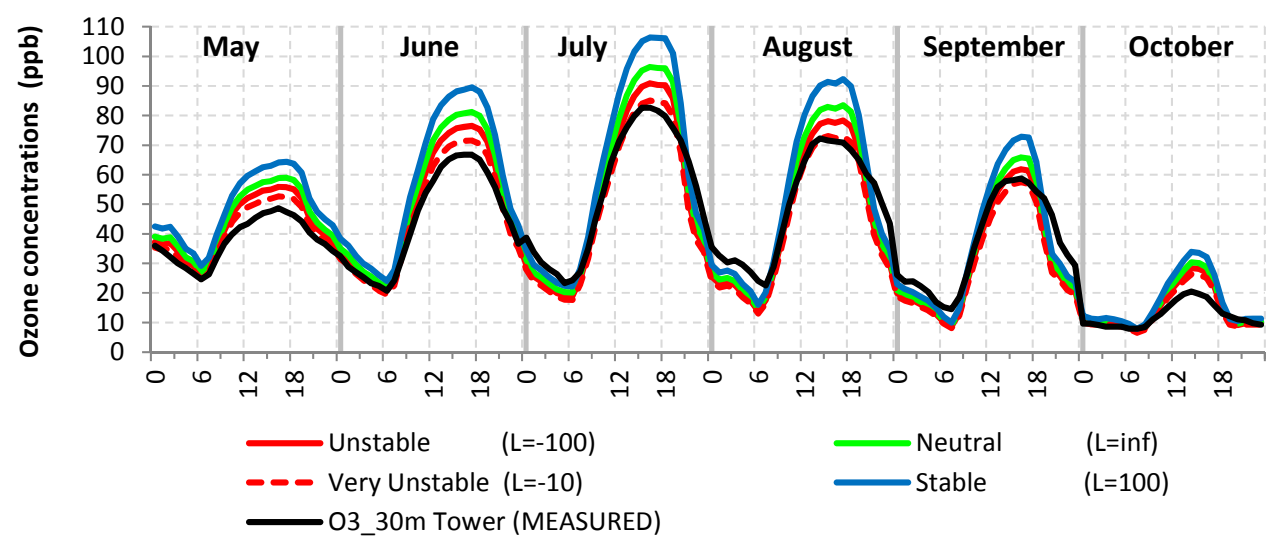

A

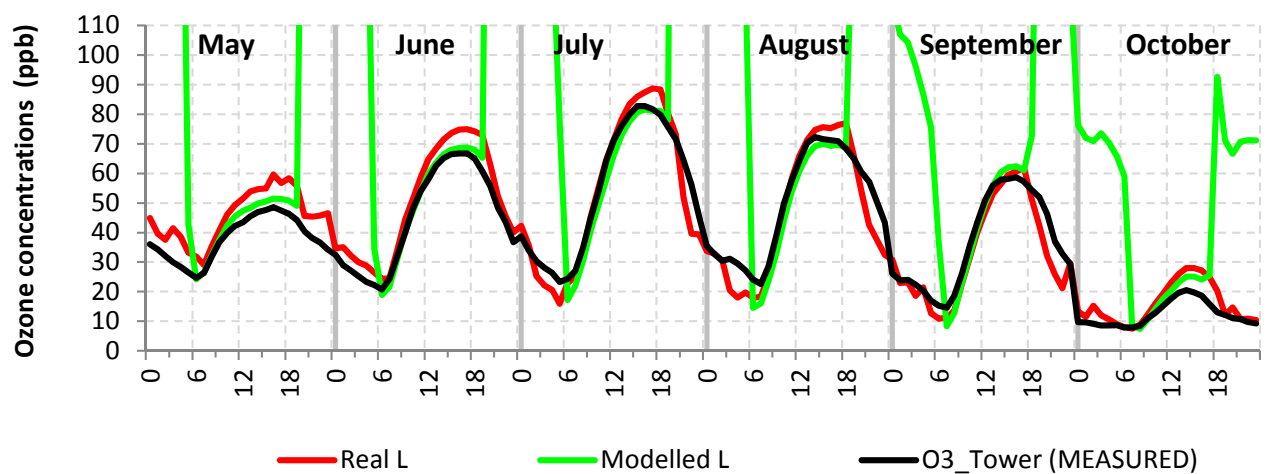

B

Figure 4. Cont. 


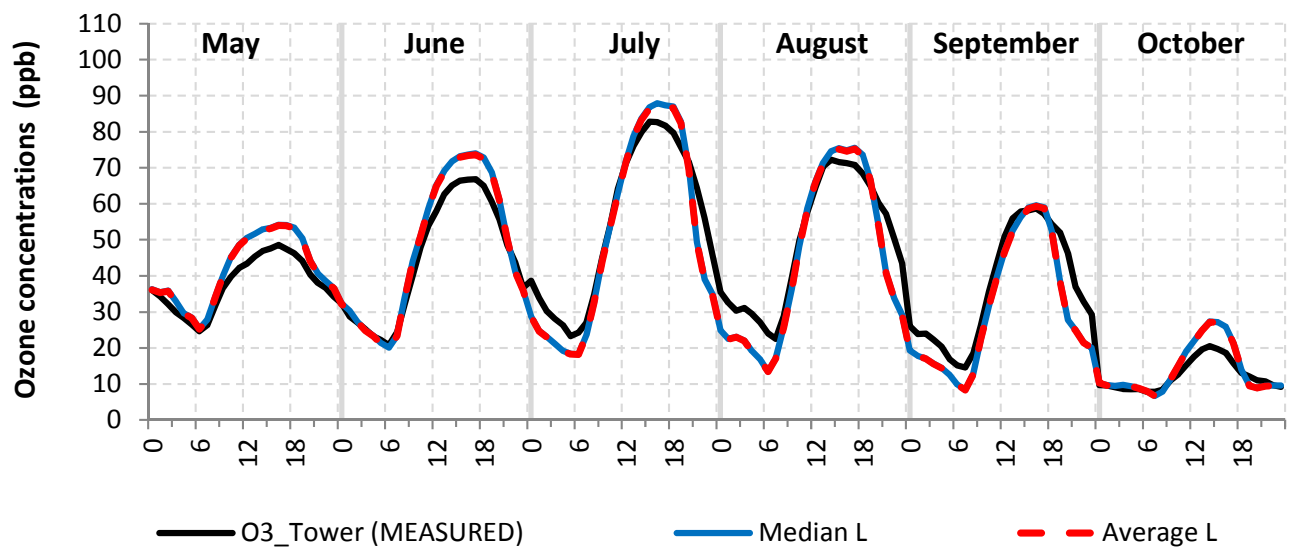

C

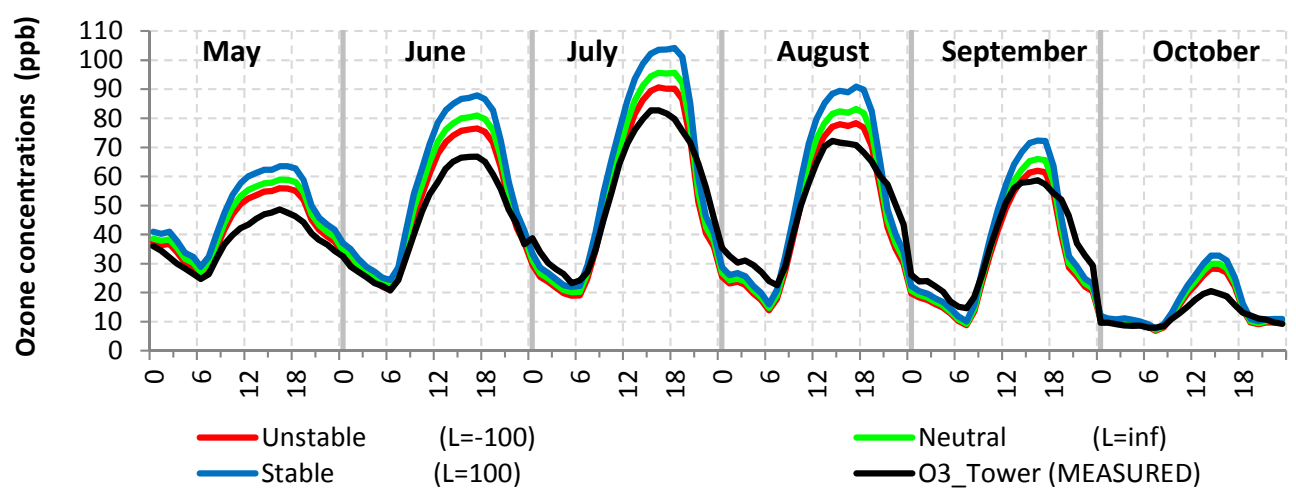

D

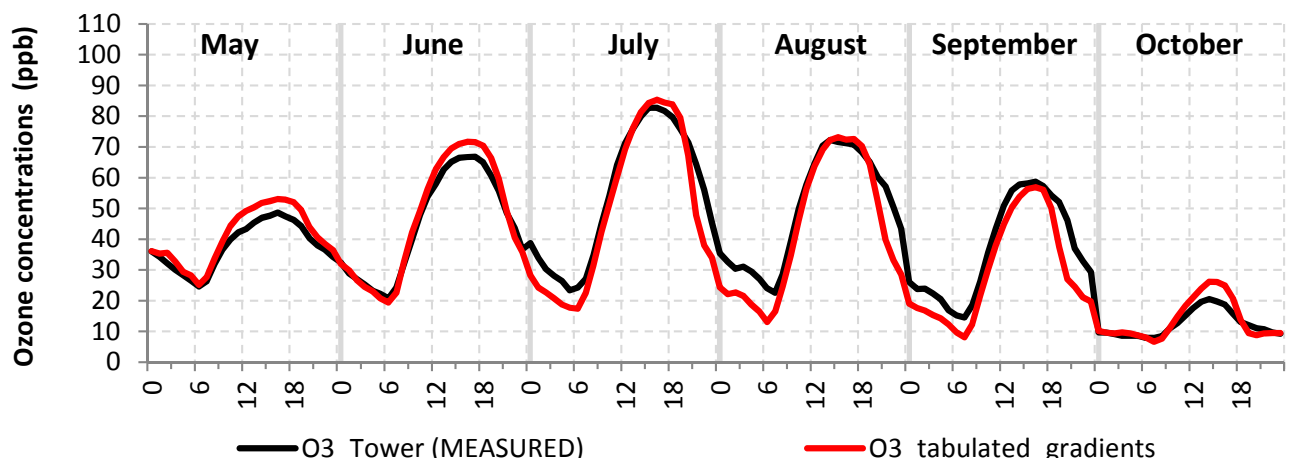

E

Figure 4. Cont. 


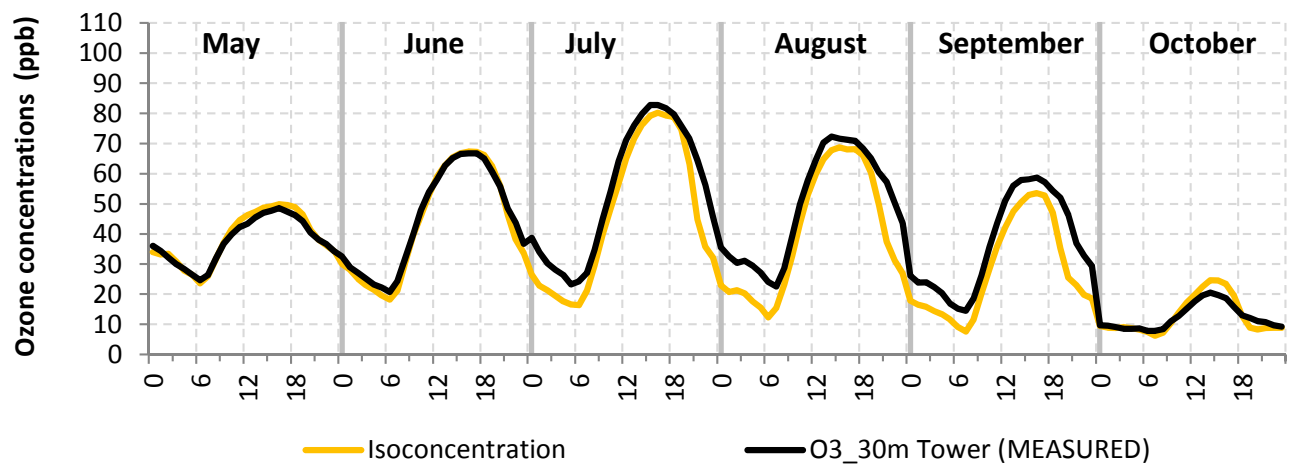

$\mathrm{F}$

Figure 4. Average daily course of ozone concentrations estimated at $30 \mathrm{~m}$ a.g.l. above the forest in the indicated months by following the different calculation options (see text): A theoretical stability (option 1); B actual stability (options 2A and 2B); C average stability (option 3); D ozone above grassland (option 4); E tabulated gradients (option 5); F isoconcentration (option 6). For comparison purpose: the Neutral case of option 1 (Figure 4A) is the output of the current version of the DO3SE model.

The consequences of the different options for the estimation of the top-canopy $\mathrm{O}_{3}$ concentrations on the $\mathrm{POD}_{1}$ calculated for a top-canopy leaf are described in Figure 5.

When the theoretical stability classes are used (option 1), the best match between the $\mathrm{POD}_{1}$ estimated by this calculation procedure and the one obtained from the EC measurements was obtained assuming very unstable atmospheric conditions, which were by far the most frequent conditions at the testing site during the hours when stomata were open (Figure 5A). At the end of the summer semester, the $\mathrm{POD}_{1}$ calculated with neutral stability conditions perfectly matched the one derived from EC: 12.965 vs. $12.975 \mathrm{mmol} \mathrm{O}_{3} \mathrm{~m}^{-2}$. When neutral stability conditions are assumed, as in the Mapping Manual [16], the $\mathrm{POD}_{1}$ at the end of the season overestimated by $18 \%$ the one obtained from the EC measurements (Table 3).

Even when the actual hourly stability values were used (option 2), both taken from the measurements or modelled, the $\mathrm{POD}_{1}$ estimations were satisfactory, and only slight overestimations between $3 \%$ and $8 \%$ were obtained (Table 3). Similar results with overestimations between $4 \%$ and $5 \%$ were obtained when a unique seasonally averaged value of the stability indicator L was used (option 3).

The worst results were obtained when the top-forest ozone concentrations were assumed to be identical to those calculated above the reference surface at the same height of the forest (Figure 5D). With this option (option 4), a $\mathrm{POD}_{1}$ overestimation of $21 \%$ was obtained in neutral conditions.

On the contrary, the $\mathrm{POD}_{1}$ calculated with the $\mathrm{O}_{3}$ concentrations obtained from the tabulated gradients of the Mapping Manual (option 5) was in perfect agreement with the one obtained from the EC measurements (Table 3): 13.003 vs. $19.972 \mathrm{mmol} \mathrm{O}_{3} \mathrm{~m}^{-2}$.

Finally, a $-7 \%$ to $-8 \%$ underestimation of the $\mathrm{POD}_{1}$ was obtained when no vertical gradient corrections were made on the $\mathrm{O}_{3}$ concentration measured at $2 \mathrm{~m}$ above the grassland field nearby. 


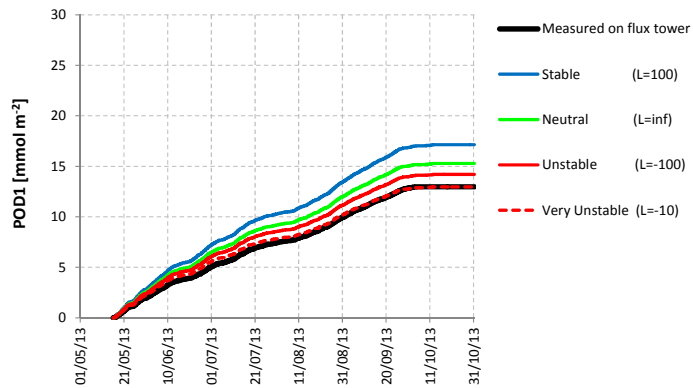

A

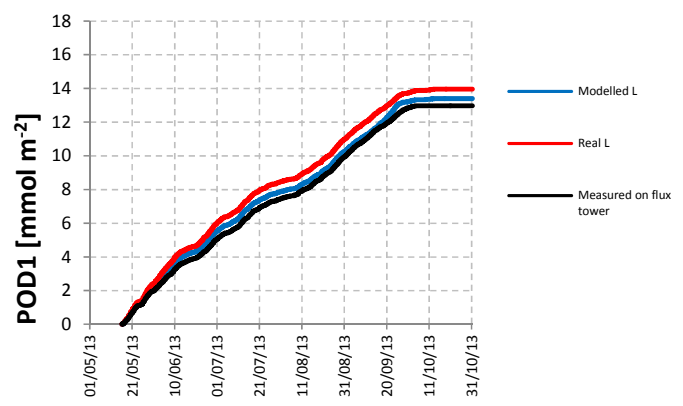

B

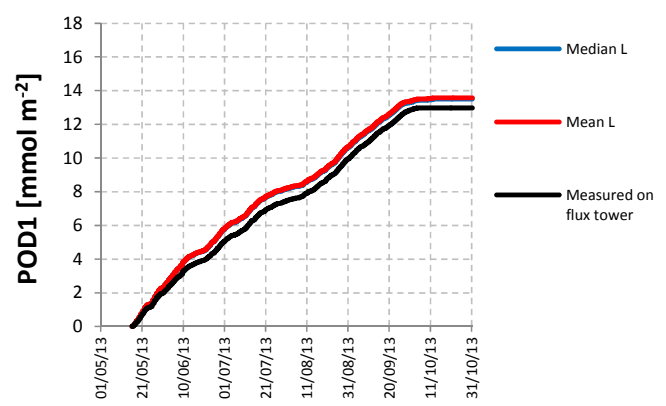

C

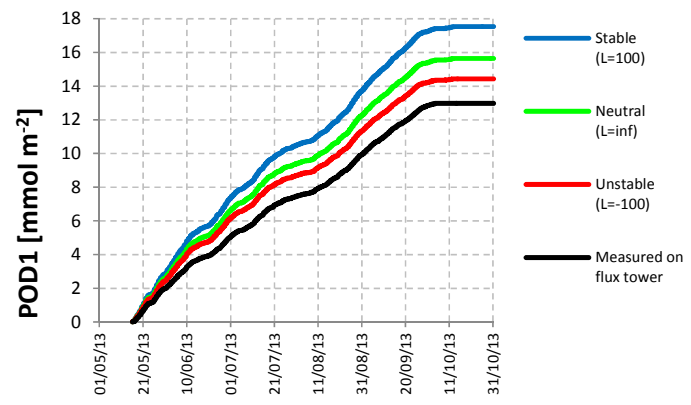

D

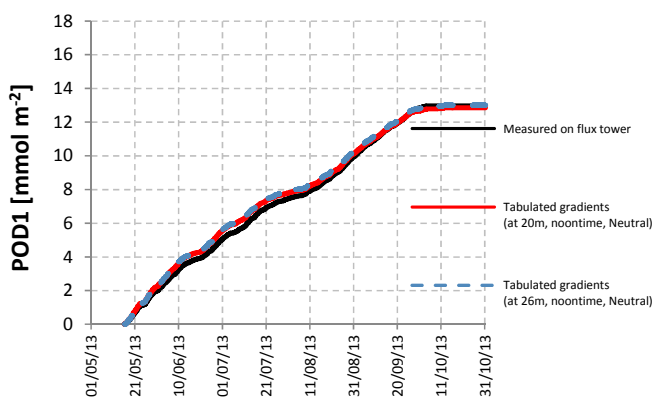

E

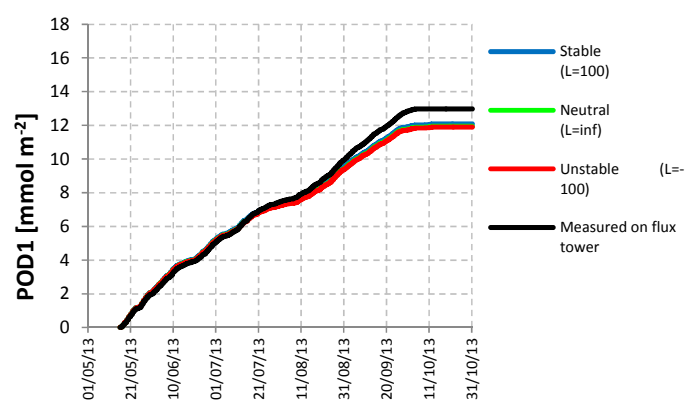

F

Figure 5. Phytotoxic Ozone Dose $\left(\mathrm{POD}_{1}\right.$ ) for a top-canopy leaf: comparison of the $\mathrm{POD}_{1}$ obtained from the eddy covariance (EC) measurements and the $\mathrm{POD}_{1}$ calculated with the different calculation options (see text): A theoretical stability (option 1); B actual stability (options 2A and 2B); C average stability (option 3); D ozone above grassland (option 4); E tabulated gradients (option 5); $\mathbf{F}$ isoconcentration (option 6). For comparison purpose: the Neutral case of option 1 (Figure 5A) is the output of the current version of the DO3SE model. 
Table 3. Differences between the $\mathrm{POD}_{1}$ obtained from the EC measurements and the $\mathrm{POD}_{1}$ calculated with the different calculation options (see text). For comparison purpose: the Neutral case of option 1 is the output of the current version of the DO3SE model.

\begin{tabular}{|c|c|c|c|}
\hline Calculation options & & & $\begin{array}{l}\text { Diff. with the measured } \\
\text { top-canopy } \text { POD }_{1}\end{array}$ \\
\hline \multirow[t]{4}{*}{ 1-Theoretical stability } & Stable & $(L=100 \mathrm{~m})$ & $+32 \%$ \\
\hline & Neutral & $(L \rightarrow \infty \mathrm{m})$ & $+18 \%$ \\
\hline & Unstable & $(L=-100 \mathrm{~m})$ & $+9 \%$ \\
\hline & Very Unstable & $(L=-10 \mathrm{~m})$ & $0 \%$ \\
\hline \multirow[t]{2}{*}{ 2-Actual stability } & Real stability & (measured $L$ ) & $+8 \%$ \\
\hline & Modelled stability & (estimated $L$ ) & $+3 \%$ \\
\hline \multirow{2}{*}{ 3-Aver. actual stability } & Mean stability & $(L=28.2 \mathrm{~m})$ & $+4 \%$ \\
\hline & Median stability & $(L=32.4 \mathrm{~m})$ & $+5 \%$ \\
\hline \multirow[t]{3}{*}{ 4-Gradients on ref. veg } & Stable & $(L=100 \mathrm{~m})$ & $+35 \%$ \\
\hline & Neutral & $(L \rightarrow \infty \mathrm{m})$ & $+21 \%$ \\
\hline & Unstable & $(L=-100 \mathrm{~m})$ & $+11 \%$ \\
\hline \multirow{4}{*}{$\begin{array}{l}\text { 5-Tab. gradients at } 26 \mathrm{~m} \\
\text { 6-Isoconcentration }\end{array}$} & & & $0 \%$ \\
\hline & Stable & $(L=100 \mathrm{~m})$ & $-7 \%$ \\
\hline & Neutral & $(L \rightarrow \infty \mathrm{m})$ & $-8 \%$ \\
\hline & Unstable & $(L=-100 \mathrm{~m})$ & $-8 \%$ \\
\hline
\end{tabular}

\section{Discussion}

The results show that the best estimations of the forest-top ozone concentrations and of the consequent Phytotoxic Ozone Dose $\mathrm{POD}_{1}$ are obtained when the typical instability conditions of the test site are considered, and even when the tabulated vertical gradient of the Mapping Manual is used.

The latter methodology was obtained from multiple runs of the EMEP deposition module with the meteorology of about 30 sites across Europe, and represents the average conditions at noon above a fully developed crop/forest. Being the atmosphere typically unstable at noon during the summer, it is not surprising that the $\mathrm{POD}_{1}$ estimated with this methodology fits very well with the measured one. This methodology is the easiest to use compared to the other, and the approach is the most pragmatic one, but we envisage that these results could not be confirmed in all environmental conditions.

On the contrary, the methodologies that require the calculation of the actual hourly L (option 2 with the modeled L, and option 3 with both average and median values of the measured L) are the most scientifically sound but also the most laborious ones. However, the calculation efforts do not always lead to the optimal performances.

The methodology which employs a unique value of $L$ (option 1 ) allows us to significantly reduce the calculation efforts required to adapt the results to the typical stability conditions of the site. However, optimal performances are reached only when a suitable value of $\mathrm{L}$ corresponding to the typical stability conditions is chosen ( $L=-10$ in our testing case), otherwise a general overestimation is expected.

Regardless of the attempt to include the effects of the atmospheric stability, the methodologies that try to excessively simplify the gradient calculation-both completely neglecting the presence of the forest (option 4) or the presence of a vertical ozone gradient (option 6) -lead to significant estimation biases, both as overestimation (option 4) or underestimation (option 6).

In any case, it is worth noting that, in the neutral conditions implicitly assumed by the Mapping Manual methodology for gradient calculations, the $\mathrm{POD}_{1}$ estimations are generally overestimated.

Since the ozone analyzers and the sampling systems employed to detect the ozone concentrations have accuracies of $1 \mathrm{ppb}$ and precisions between 1 and $2 \mathrm{ppb}$, any bias in the $\mathrm{O}_{3}$ measurements can also have an effect on the POD1 estimation. For the four best calculation options (option 1 with unstable conditions, option 2 with modeled L, option 3 with mean measured L, option 5), the introduction of biases of $-2 \mathrm{ppb}$ and $+2 \mathrm{ppb}$ in the $\mathrm{O}_{3}$ concentrations resulted in changes between $-6 \%$ and $+7 \%$ of the $\mathrm{POD}_{1}$ estimated with the respective options (Table 4 ). The changes are limited to $+3.5 \%$ on average 
if a bias of $+1 \mathrm{ppb}$ in $\mathrm{O}_{3}$ concentration is introduced, with a maximum deviation shown in the case of the tabulated gradients.

Table 4. Sensitivity of $\mathrm{POD}_{1}$ estimations to inaccuracies in $\mathrm{O}_{3}$ concentration measurements. The four best performing options and the current methodology in the Mapping Manual are presented.

\begin{tabular}{cccccc}
\hline Calculation options & & $\begin{array}{c}\text { Agreement with } \\
\text { POD1 measured }\end{array}$ & $\mathbf{+ 1} \mathbf{p p b}$ & $\mathbf{+ 2} \mathbf{p p b}$ & $\mathbf{- 2} \mathbf{p p b}$ \\
\hline 1-Theoretical stability & Very Unstable $(L=-10 \mathrm{~m})$ & $0 \%$ & $3 \%$ & $7 \%$ & $-6 \%$ \\
2-Actual stability & $\begin{array}{c}\text { Modelled stability } \\
(\text { estimated } L)\end{array}$ & $3 \%$ & $4 \%$ & $7 \%$ & $-7 \%$ \\
3-Aver. actual stability & Mean stability $(L=28.2 \mathrm{~m})$ & $4 \%$ & $3 \%$ & $6 \%$ & $-7 \%$ \\
5-Tab. Gradients at 26 $\mathrm{m}$ & & $0 \%$ & $5 \%$ & $9 \%$ & $-5 \%$ \\
Current Mapping Manual & Neutral $(L \rightarrow \infty \mathrm{m})$ & $18 \%$ & $3 \%$ & $6 \%$ & $-6 \%$ \\
\hline
\end{tabular}

These changes in $\mathrm{POD}_{1}$ estimations are not negligible and highlight the need for special attention to the measuring systems in order to get accurate and precise $\mathrm{O}_{3}$ measurements. Frequent instrument calibrations and checks, as well as filter changes, are thus needed.

\section{Conclusions}

The calculation of vertical ozone gradients is needed to avoid erroneous $\mathrm{POD}_{1}$ and exposure estimations.

The introduction of the atmospheric stability in the DO3SE scheme for the $\mathrm{POD}_{1}$ calculation improves the accuracy of the stomatal dose estimation compared to that which is obtainable with the current version which implies neutral stability conditions. Actually, in the latter case, an overestimation of $\mathrm{O}_{3}$ concentrations by $15 \%$ as a median value on a $24-\mathrm{h}$ basis has been observed. This feature is likely to be valid in all environmental conditions since the methodology is adaptive.

The tabulated gradients methodology described in the UN/ECE Mapping Manual seems to combine simplicity with good estimation performance on a whole-season time frame, but we fear that this result could not be confirmed in all the different environmental conditions.

Tests on other suitable datasets where eddy covariance flux measurements are available are recommended.

Methodologies that try to excessively simplify the calculation of ozone vertical gradients or that completely neglect the presence of a vertical ozone gradient lead to significant estimation biases.

Inaccuracies in instrumental measurements also have a significant effect on the final $\mathrm{POD}_{1}$ estimation for forests.

Acknowledgments: The authors are grateful to Sabine Braun for having firstly suggested the need of this comparison and to J.P. Tuovinen, D. Simson, L. Grünhage and P. Büker for their valuable contribute on the discussions on this topic in the frame of the ICP-Vegetation programme. The author thanks also G. Mills and $\mathrm{H}$. Harmens of the ICP-Vegetation coordination centre for their precious support. This work was intended as a follow-up of the European FP7 project ECLAIRE and of the Italian research program PRIN TreeCity. This publication has been funded by the Catholic University of the Sacred Heart in the frame of its Programs of promotion and dissemination of the scientific research.

Author Contributions: Giacomo Gerosa conceived the work; defined the formulations of the vertical gradients used in the paper, implemented the DO3SE model with the above mentioned formulations and contributed to writing the paper; Angelo Finco provided the eddy covariance measurements and their analysis, and made all the simulations; Riccardo Marzuoli, contributed to the analysis of the eddy covariance measurements and to writing the paper; Maria Chiesa and Beatrice Monteleone provided the $\mathrm{O}_{3}$ concentration data at ground level, contributed to their elaboration and to writing the paper and the appendix.

Conflicts of Interest: the authors declare no conflict of interest. 


\section{Appendix A}

\section{Estimation of the Obukhov Length (L)}

The Obukhov length $L(m)$ is an indicator of the atmospheric stability, but its calculation requires that some other parameters are estimated aside. $L$ is defined by the following equation:

$$
L=-\frac{u_{*}^{3}}{k \frac{g}{T} \frac{H}{\rho c_{p}}}
$$

where $u^{*}$ is the friction velocity $(\mathrm{m} / \mathrm{s}), k$ is the Von Kármán constant $(0.41$, adim $), g$ is the gravity acceleration $\left(9.8 \mathrm{~m} \mathrm{~s}^{-2}\right), T$ is the air temperature $(\mathrm{K}), H$ is the sensible heat flux $\left(\mathrm{W} \mathrm{m}^{-2}\right), \rho$ is the air density $\left(\mathrm{kg} \mathrm{m}^{-3}\right), c_{p}$ is the specific heat at constant pressure $\left(1048 \mathrm{~J} \mathrm{~kg}^{-1} \mathrm{~K}^{-1}\right)$.

Not all these data are usually available from traditional slow meteorological stations, in particular $u^{*}$ and $H$. Relatively easy measurements of $u^{*}$ and $H$ can be performed with an ultrasonic anemometer but it is rarely available.

Hence, to estimate $L$, a modelisation of $H$ and $u^{*}$, and also of the net radiation $\left(R_{n}\right)$ which is required for the $H$ estimation, are needed.

\section{Estimation of the Net Radiation $\left(\mathbf{R}_{\mathbf{n}}\right)$}

Net radiation can be estimated using the methodology proposed by Holtslag and Van Ulden [37]:

$$
R_{n}=\frac{\left((1-A) Q_{s w}+c_{1} T^{6}-\sigma T^{4}+c_{2} N\right)}{1+c_{3}}
$$

where $A$ is the albedo (a value between 0 and 1 ), $T$ is the air temperature $\mathrm{K}$ ), $N$ is the cloud cover $(\%), c_{1}$ and $c_{2}$ are constants (whose values are respectively $5.31 \cdot 10^{-13} \mathrm{~W} \mathrm{~m}^{-2}$ and $60 \mathrm{~W} \mathrm{~m}^{-2}$ ), $\sigma$ is the Stefan-Boltzmann constant $\left(5.67 \times 10^{-8} \mathrm{~W} \mathrm{~m}^{-2} \mathrm{~K}^{-4}\right), Q_{S W}$ is the shortwave radiation (the global radiation which is typically available from traditional meteorological stations, expressed in $\mathrm{W} \mathrm{m}^{-2}$ ) and $c_{3}$ is a temperature-dependent parameter which will be presented a few lines below.

The cloud cover $N$ can be estimated from the measured shortwave radiation taking into account the solar elevation angle ( $v$, expressed in degrees) with the following equation taken from Holtslag and Van Ulden [37]:

$$
N=\sqrt[b_{2}]{\frac{1}{b_{1}}\left(1-\frac{Q_{S W}}{(990 \sin v-30)}\right)}
$$

where $b_{1}$ and $b_{2}$ are empirical constants whose values are respectively 0.75 and 3.4.

The solar elevation angle $v$ can be calculated by downloading the tool available from the NOAA (National Oceanic and Atmospheric Administration) [38].

The $c_{3}$ parameter is obtained from the following equation:

$$
c_{3}=0.38 \cdot((1-\alpha) \cdot S+1) /(S+1)
$$

where $\alpha$ is the water availability parameter described in Beljaars and Holtslag [39,40] and whose values can be taken from Table A1 [41], and $S$ is a temperature-dependent parameter described by the following equation derived from the tabulated values [41]:

$$
S=1.5 \cdot e^{-0.060208041 \cdot T}
$$

where $T$ is the air temperature in Celsius degrees. 


\section{Estimation of the Sensible Heat Flux (H)}

Sensible heat fluxes can be modelled using the methodology proposed by Holtslag and Van Ulden [37]:

$$
H=\frac{(1-\alpha)+S}{1+S}\left(R_{n}+Q_{A}-G\right)-\alpha \beta
$$

where $Q_{A}$ is the anthropogenic heat flux (which is always set equal to zero as suggested by Hanna and Chang [41], $S$ and $\alpha$ are respectively the temperature-dependent parameter and the water availability parameter just described a few lines above (Equation (22) and Table A1), $\beta$ is a constant value equal to $20 \mathrm{~W} \mathrm{~m}^{-2}$ which takes into account that sensible heat flux is usually negative just before the sunset [41], and $G$ is the ground heat flux assumed as a fraction of the net radiation

$$
G=a \cdot R_{n}
$$

with $a$ a constant value ( $a=0.1$ for rural areas and $a=0.3$ for urban areas) taken from Doll et al. [42].

During the nighttime hours $\left(R n<50 \mathrm{~W} \mathrm{~m}^{-2}\right)$, the sensible heat flux is calculated as $H=-\alpha \beta$.

Table A1. Values for the parameter $\alpha$ proposed by Hanna and Chang [41].

\begin{tabular}{ccc}
\hline & & Values for the Parameter $\alpha$ \\
\hline From & To & Description \\
0 & 0.2 & Arid desert without rainfalls for months \\
0.2 & 0.4 & Rural arid area \\
0.4 & 0.6 & Agricultural fields in periods with no rainfalls for long periods \\
0.5 & 1 & Urban environment \\
0.8 & 1.2 & Agricultural fields or forests with sufficient water availability \\
1.2 & 1.4 & Big lake or ocean, far at least 10 km from the shore \\
\hline
\end{tabular}

\section{Estimation of the Friction Velocity $\left(\mathrm{u}^{*}\right)$}

The friction velocity can be estimated following the methodology proposed in Bassin et al. [43]. When $H<1 \mathrm{~W} \mathrm{~m}^{-2}$ (Stable atmosphere), $u^{*}$ is calculated using the following equation:

$$
u^{*}=\frac{0.5 k \cdot U}{\ln \left(\left(z_{r e f}-d\right) / z_{0}\right)}\left(1+\sqrt{1-\frac{4\left(5 \cdot g \cdot z_{r e f} \cdot \theta_{*} \cdot \ln \left(\left(z_{r e f}-d\right) / z_{0}\right)\right.}{k \cdot T_{0} \cdot U}}\right)
$$

where $k$ is the Von Kármán constant, $U$ is the horizontal wind speed $\left(\mathrm{m} \mathrm{s}^{-1}\right), z_{r e f}$ is the measurement height of the wind speed $(\mathrm{m}), d$ is the displacement height $(\mathrm{m})$ usually taken as two-thirds of the canopy height, $T_{0}$ are the Kelvin degrees at $0{ }^{\circ} \mathrm{C}$ (i.e., $\left.T_{0}=273.15 \mathrm{~K}\right), z_{0}$ is the roughness length $(\mathrm{m})\left(z_{0}\right.$ values can be taken from the table on page 1.5-12 of WMO (World Meteorological Organisation) [44]), $g$ is the gravity acceleration $\left(\mathrm{m} \mathrm{s}^{-2}\right)$ and $\theta^{*}$ is the scale temperature $(\mathrm{K})$ calculated according to the following equation:

$$
\theta^{*}=\frac{-H}{\rho \cdot c_{p} \cdot u_{\text {neutral }}^{*}}
$$

where $u_{\text {neutral }}^{*}\left(\mathrm{~m} \mathrm{~s}^{-1}\right)$ is calculated using the following equation:

$$
u_{\text {neutral }}^{*}=\frac{U}{k \ln \left(\left(z_{\text {ref }}-d\right) / z_{0}\right)}
$$


When $H>1 \mathrm{~W} \mathrm{~m}^{-2}$ (unstable atmosphere) the friction velocity is calculated using the following equation:

$$
u^{*}=\frac{k U}{\ln \left[\left(z_{r e f}-d\right) / z_{0}\right]}\left[1+d_{1} \ln \left(1+d_{2} d_{3}\right)\right]
$$

where $d_{1}, d_{2}$ and $d_{3}$ are respectively:

$$
\begin{gathered}
d_{1}=\left\{\begin{array}{cc}
0.128+0.005 \ln \left[\frac{z_{0}}{\left(z_{r e f}-d\right)}\right] & \text { if } \frac{z_{0}}{z_{r e f}-d} \leq 0.01 \\
0.107 & \text { if } \frac{z_{0}}{z_{r e f}-d}>0.01
\end{array}\right. \\
d_{2}=1.95+32.6\left(\frac{z_{0}}{z_{r e f}-d}\right)^{0.45} \\
d_{3}=\frac{H}{\rho c_{p}} \frac{k g\left(z_{r e f}-d\right)}{T_{0}}\left(\frac{\ln \left(\left(z_{r e f}-d\right) / z_{0}\right)}{k U}\right)^{3}
\end{gathered}
$$

\section{References}

1. Paoletti, E.; de Marco, A.; Beddows, D.C.; Harrison, R.M.; Manning, W.J. Ozone levels in European and USA cities are increasing more than at rural sites, while peak values are decreasing. Environ. Pollut. 2014, 192, 295-299. [CrossRef] [PubMed]

2. Büker, P.; Feng, Z.; Uddling, J.; Briolat, A.; Alonso, R.; Braun, S.; Elvira, S.; Gerosa, G.; Karlsson, P.E.; Le Thiec, D.; et al. New flux based dose-response relationships for ozone for European forest tree species. Environ. Pollut. 2015, 206, 163-174. [CrossRef] [PubMed]

3. Marzuoli, R.; Monga, R.; Finco, A.; Gerosa, G. Biomass and physiological responses of Quercus robur (L.) young trees during 2 years of treatments with different levels of ozone and nitrogen wet deposition. Trees 2016, 30, 1995-2010. [CrossRef]

4. Sicard, P.; de Marco, A.; Dalstein-Richier, L.; Tagliaferro, F.; Renou, C.; Paoletti, E. An epidemiological assessment of stomatal ozone flux-based critical levels for visible ozone injury in Southern European forests. Sci. Total Environ. 2016, 541, 729-741. [CrossRef] [PubMed]

5. Ochoa-Hueso, R.; Munzi, S.; Alonso, R.; Arroniz-Crespo, M.; Avila, A.; Bermejo, V.; Bobbink, R.; Branquinho, C.; Concostrina-Zubiri, L.; Cruz, C.; et al. Ecological impacts of atmospheric pollution and interactions with climate change in terrestrial ecosystems of the Mediterranean Basin: Current research and future directions. Environ. Pollut. 2017, 227, 194-206. [CrossRef] [PubMed]

6. Makar, P.A.; Staebler, R.M.; Akingunola, A.; Zhang, J.; McLinden, C.; Kharol, S.K.; Pabla, B.; Cheung, P.; Zheng, Q. The effects of forest canopy shading and turbulence on boundary layer ozone. Nat. Commun. 2017, 8. [CrossRef] [PubMed]

7. Wesely, M.L.; Hicks, B.B. Some factors that affect the deposition rates of sulfur dioxide and similar gases on vegetation. J. Air Pollut. Control Assoc. 1977, 27, 1110-1116. [CrossRef]

8. Wolfe, G.M.; Thornton, J.A.; McKay, M.; Goldstein, A.H. Forest-atmosphere exchange of ozone: Sensitivity to very reactive biogenic VOC emissions and implications for in-canopy photochemistry. Atmos. Chem. Phys. 2011, 11, 7875-7891. [CrossRef]

9. De Arellano, J.V.G.; Duynkerke, P.G. Influence of chemistry on the flux-gradient relationships for the NO-O3-NO2 system. Bound.-Layer Meteorol. 1992, 61, 375-387. [CrossRef]

10. Tuovinen, J.P.; Simpson, D. An aerodynamic correction for the European ozone risk assessment methodology. Atmos. Environ. 2008, 42, 8371-8381.

11. Grünhage, L.; Haenel, H.D.; Jäger, H.J. The exchange of ozone between vegetation and atmosphere: Micrometeorological measurement techniques and models. Environ. Pollut. 2000, 109, 373-392. [CrossRef]

12. Finnigan, J. Turbulence in plant canopies. Annu. Rev. Fluid Mech. 2000, 32, 519-571. [CrossRef] 
13. Katul, G.; Cava, D.; Poggi, D.; Albertson, J.; Mahrt, L. Stationarity, Homogeneity, and Ergodicity in Canopy Turbulence. In Handbook of Micrometeorology; Lee, X., Massman, W., Law, B., Eds.; Springer: Dordrecht, The Netherlands, 2004; volume 29.

14. Tuovinen, J.P.; Emberson, L.; Simpson, D. Modelling ozone fluxes to forests for risk assessment: Status and prospects. Ann. For. Sci. 2009, 66, 1-14. [CrossRef]

15. Emberson, L.D.; Ashmore, M.R.; Cambridge, H.M.; Simpson, D.; Tuovinen, J.P. Modelling stomatal ozone flux across Europe. Environ. Pollut. 2000, 109, 403-413. [CrossRef]

16. CLRTAP-UNECE Convention on Long-Range Transboundary Air Pollution. Mapping Critical Levels for Vegetation. Chapter III of Manual on Methodologies and Criteria for Modelling and Mapping Critical Loads and Levels and Air Pollution Effects, Risks and Trends. 2015. Available online: http:/ /icpvegetation.ceh.ac. uk/publications / documents/Ch3-MapMan-2016-05-03_vf.pdf (accessed on 15 October 2016).

17. Garratt, J.R. The atmospheric boundary layer. Earth-Sci. Rev. 1994, 37, 89-134. [CrossRef]

18. Gerosa, G.; Ballarin-Denti, A. Regional scale risk assessment of ozone and forests. Dev. Environ. Sci. 2003, 3, 119-139.

19. Simpson, D.; Benedictow, A.; Berge, H.; Bergström, R.; Emberson, L.D.; Fagerli, H.; Flechard, C.R.; Hayman, G.D.; Gauss, M.; Jonson, J.E.; et al. The EMEP MSC-W chemical transport model-technical description. Atmos. Chem. Phys. 2012, 12, 7825-7865. [CrossRef]

20. Van Pul, W.A.J.; Jacobs, A.F.G. The conductance of a maize crop and the underlying soil to ozone under various environmental conditions. Bound.-Layer Meteorol. 1994, 69, 83-99. [CrossRef]

21. Monin, A.S.; Obukhov, A.M. Osnovnye zakonomernosti turbulentnogo peremesivanija v prizemnom sloe atmosfery (Basic laws of turbulent mixing in the atmosphere near the ground). Trudy geofiz. Inst. AN SSSR 1954, 24, 163-187.

22. Gerosa, G.; Finco, A.; Marzuoli, R.; Tuovinen, J.P. Evaluation of the uncertainty in the ozone flux effect modelling: From the experiments to the dose-response relationships. Atmos. Environ. 2012, 54, 44-52. [CrossRef]

23. Jarvis, P.G. The interpretation of the variations in leaf water potential and stomatal conductance found in canopies in the field. Philos. Trans. R. Soc. Lond. Ser. B: Biol. Sci. 1976, 273, 593-610. [CrossRef]

24. Büker, P.; Morrissey, T.; Briolat, A.; Falk, R.; Simpson, D.; Tuovinen, J.P.; Alonso, R.; Barth, S.; Baumgarten, M.; Grulke, N.; et al. DO3SE modelling of soil moisture to determine ozone flux to European forest trees. Atmos. Chem. Phys. Discuss. 2011, 11, 33583-33650. [CrossRef]

25. Longo, L. Rapporti Scientifici 1. Centro Nazionale Biodiversità Forestale Verona-Bosco della Fontana. In Dinamica di una foresta della Pianura Padana. Bosco della Fontana. Seconda edizione con Linee di gestione forestale; Mason, F., Ed.; Gianluigi Arcari Editore: Mantua, Italy, 2006; pp. 16-17.

26. Güsten, H.; Heinrich, G.; Schmidt, R.W.H.; Schurath, U. A novel ozone sensor for direct eddy flux measurements. J. Atmos. Chem. 1992, 14, 73-84.

27. Güsten, H.; Heinrich, G. On-line measurements of ozone surface fluxes: Part I. Methodology and instrumentation. Atmos. Environ. 1996, 6, 897-909. [CrossRef]

28. Vickers, D.; Mahrt, L. Quality Control and Flux Sampling Problems for Tower and Aircraft Data. J. Atmos. Ocean. Technol. 1997, 14, 512-526. [CrossRef]

29. Lee, X.; Massman, W.; Law, B. Handbook of Micrometeorology: A Guide for Surface Flux Measurements and Analysis; Springer: Dordrecht, The Netherlands, 2004.

30. Aubinet, M.; Vesala, T.; Papale, D. Eddy Covariance: A Practical Guide to Measurement and Data Analysis; Springer: Dordrecht, The Netherlands, 2012; p. 438.

31. Rummel, U.; Ammann, C.; Kirkman, G.A.; Moura, M.A.L.; Foken, T.; Andreae, M.O.; Meixner, F.X. Seasonal variation of ozone deposition to a tropical rain forest in southwest Amazonia. Atmos. Chem. Phys. 2007, 7 , 5415-5435. [CrossRef]

32. Muller, J.B.A.; Percival, C.J.; Gallagher, M.W.; Fowler, D.; Coyle, M.; Nemitz, E. Sources of uncertainty in eddy covariance ozone flux measurements made by dry chemiluminescence fast response analysers. Atmos. Meas. Tech. 2010, 3, 163-176. [CrossRef]

33. Webb, E.K.; Pearman, G.I.; Leuning, R. Correction of flux measurements for density effects due to heat and water vapour transfer. Q. J. R. Meteorol. Soc. 1980, 106, 85-100. [CrossRef]

34. Foken, T.; Wichura, B. Tools for quality assessment of surface-based flux measurements. Agric. For. Meteorol. 1996, 78, 83-105. [CrossRef] 
35. Gerosa, G.; Vitale, M.; Finco, A.; Manes, F.; Ballarin-Denti, A.; Cieslik, S. Ozone uptake by an evergreen Mediterranean forest (Quercus ilex) in Italy. Part I: Micrometeorological flux measurements and flux partitioning. Atmos. Environ. 2005, 39, 3255-3266. [CrossRef]

36. Gerosa, G.; Cieslik, S.; Ballarin-Denti, A. Micrometeorological determination of time-integrated stomatal ozone fluxes over wheat: A case study in Northern Italy. Atmos. Environ. 2003, 37, 777-788. [CrossRef]

37. Holtslag, A.A.; van Ulden, A.P. A simple scheme for daytime estimates of the surface fluxes from routine weather data. J. Appl. Meteorol. Climatol. 1983, 22, 517-529. [CrossRef]

38. NOAA, US Department of Commerce: National Oceanic and Atmospheric Administration. Solar Calculation Details. Available online: http://www.esrl.noaa.gov/gmd/grad/solcalc/calcdetails.html (accessed on 15 October 2016).

39. Beljaars, A.C.M.; Holtslag, A.A. A software library for the calculation of surface fluxes over land and sea. Environ. Softw. 1989, 5, 60-68. [CrossRef]

40. Beljaars, A.C.M.; Holtslag, A.A. Flux parametrization over land surfaces for atmospheric models. J. Appl. Meteorol. 1991, 30, 327-341. [CrossRef]

41. Hanna, S.R.; Chang, J.C. Boundary layer parametrizations for applied dispersion modeling over urban areas. Bound.-Layer Meteorol. 1992, 58, 229-259. [CrossRef]

42. Doll, D.; Ching, J.K.S.; Kaneshire, J. Parametrization of subsurfaces heating for soil and concrete using new radiation data. Bound.-Layer Meteorol. 1985, 32, 351-372. [CrossRef]

43. Bassin, S.; Calanca, P.; Weidinger, T.; Gerosa, G.; Fuhrer, J. Modeling seasonal ozone fluxes to grassland and wheat: Model improvement, testing and application. Atmos. Environ. 2003, 38, 2349-2359. [CrossRef]

44. WMO (World Meteorological Organization). Guide to Meteorological Instruments and Methods of Observation, 7th Edition 2008. Available online: https://www.wmo.int/pages/prog/gcos/documents/ gruanmanuals/CIMO/CIMO_Guide-7th_Edition-2008.pdf (accessed on 15 October 2016).

(C) 2017 by the authors. Licensee MDPI, Basel, Switzerland. This article is an open access article distributed under the terms and conditions of the Creative Commons Attribution (CC BY) license (http:/ / creativecommons.org/licenses/by/4.0/). 